\title{
Transdimensional ambient noise tomography of Bass Strait, southeast Australia, reveals the sedimentary basin and deep crustal structure beneath a failed continental rift
}

\author{
E. Crowder, ${ }^{1}$ N. Rawlinson, ${ }^{2}$ S. Pilia, ${ }^{2}$ D. G. Cornwell ${ }^{\oplus 1}$ and A.M. Reading ${ }^{3}$ \\ ${ }^{1}$ School of Geosciences, University of Aberdeen, Aberdeen AB243UE, Scotland, UK. E-mail: emily.crowder@abdn.ac.uk \\ ${ }^{2}$ Department of Earth Sciences, University of Cambridge, Cambridge, Cambridgeshire CB30EZ, UK \\ ${ }^{3}$ School of Natural Sciences (Physics), University of Tasmania, Hobart, Tasmania 7001, Australia
}

Accepted 2019 January 29. Received 2019 January 22; in original form 2018 June 8

\begin{abstract}
SUMMAR Y
Debate is ongoing as to which tectonic model is most consistent with the known geology of southeast Australia, formerly part of the eastern margin of Gondwana. In particular, numerous tectonic models have been proposed to explain the enigmatic geological relationship between Tasmania and the mainland, which is separated by Bass Strait. One of the primary reasons for the lack of certainty is the limited exposure of basement rocks, which are masked by the sea and thick Mesozoic-Cenozoic sedimentary and volcanic cover sequences. We use ambient noise tomography recorded across Bass Strait to generate a new shear wave velocity model in order to investigate crustal structure. Fundamental mode Rayleigh wave phase velocity dispersion data extracted from long-term cross-correlation of ambient noise data are inverted using a transdimensional, hierarchical, Bayesian inversion scheme to produce phase velocity maps in the period range 2-30 s. Subsequent inversion for depth-dependent shear wave velocity structure across a dense grid of points allows a composite 3-D shear wave velocity model to be produced. Benefits of the transdimensional scheme include a data-driven parametrization that allows the number and distribution of velocity unknowns to vary, and the data noise to also be treated as an unknown in the inversion. The new shear wave velocity model clearly reveals the primary sedimentary basins in Bass Strait as slow shear velocity zones which extend down to $14 \mathrm{~km}$ in depth. These failed rift basins, which formed during the early stages of Australia-Antarctica break-up, appear to be overlying thinned crust, where high velocities of 3.8 $4.0 \mathrm{~km} \mathrm{~s}^{-1}$ occur at depths greater than $20 \mathrm{~km}$. Along the northern margin of Bass Strait, our new model is consistent with major tectonic boundaries mapped at the surface. In particular, we identify an east dipping velocity transition zone in the vicinity of the Moyston Fault, a major tectonic boundary between the Lachlan and Delamerian orogens, which are part of the Phanerozoic accretionary terrane that makes up eastern Australia. A pronounced lineament of high shear wave velocities $\left(\sim 3.7-3.8 \mathrm{~km} \mathrm{~s}^{-1}\right)$ in the lower crust of our new model may represent the signature of relict intrusive magmatism from failed rifting in the early stages of Australia-Antarctica break-up along a crustal scale discontinuity in the Selwyn Block microcontinent which joins Tasmania and Victoria.
\end{abstract}

Key words: Australia; Inverse theory; Seismic noise; Seismic tomography; Crustal structure.

\section{INTRODUCTION}

The Australian continent can be divided into two broad regions of different ages. The western two-thirds of the continent is of Archean to Proterozoic provenance, while the much younger eastern third of the continent, commonly known as the Tasmanides, was largely formed in the Palaeozoic. The Tasmanides are thought to be a series of convergent orogenic belts, which formed as a result of long-term accretion onto the eastern edge of the supercontinent Gondwana from the Neoproterozoic to the Cretaceous (Glen 2013). The southern part of the Tasmanides is composed of two main orogenic belts, the Delamerian-Ross Orogen (Neoproterozoic to Early Ordovician; Stump et al. 1986; Flottmann et al. 1993) and the Lachlan Orogen (Palaeozoic; Fergusson \& Coney 1992).

The eastern margin of east Gondwana between Australia and Antarctica is complex, with Tasmania considered a key component, 
yet is rarely included in large-scale tectonic reconstructions. This is due to the number and variety of tectonic models proposed for the geological relationship between mainland Australia and Tasmania. Despite their proximity, the variations in geology between Victoria (SE Australia) and Tasmania are substantial; there are significant contrasts in rock ages, depositional environments and the timing and degree of metamorphism (Moore et al. 2013). Numerous studies have tried to piece together the tectonic evolution of the region, offering a range of often contradictory models to explain their observations (e.g. Sproll \& Dietz 1969; Li et al. 1997; Teasdale et al. 2003; Boger \& Miller 2004; Cawood 2005; Cayley 2011; Gibson et al. 2011; White et al. 2013). A solution to the problem has proven to be particularly difficult due to the lack of outcrop. Apart from a small number of islands in Bass Strait, there is little in the way of a rock record that can provide a direct evidence for competing theories. In addition to the inaccessibility of outcrops, large areas of crust are blanketed in thick sedimentary sequences, namely the Bass, Gippsland and Otway basins. These basins, along with more recent volcanics, obscure deeper basement geology and structures that could provide clues about the Tasmania-Victoria tectonic relationship. To mitigate these limitations, the aim of this study is to apply seismic imaging methods which are capable of penetrating through the younger cover sequences in order to remotely sample the basement beneath, thereby providing new insight into the tectonic setting of this region. We examine our results with respect to a recent model that has been postulated to explain the Tasmania - mainland Australia link, namely the Selwyn Block model. This model implies a pre-Cambrian basement connection between Tasmania and Victoria based in part on an apparent correlation of $\sim \mathrm{N}-\mathrm{NE}$ trending magnetic anomalies across Bass Strait (Cayley et al. 2002). Cayley (2011) proposed that Tasmania and central Victoria, as the Selwyn Block, were part of a microcontinental block (VanDieland) that became entrained in the subduction-accretion system that formed the Palaeozoic orogens which now comprise eastern Australia.

To date, potential field imaging and modelling (e.g. Leaman et al. 1994; Gunn et al. 1997a,b; Morse et al. 2009; McLean et al. 2010; Moore et al. 2016), seismic reflection profiling (Drummond et al. 2000; Cayley et al. 2011) and seismic tomography (Rawlinson \& Kennett 2008, Pilia et al. 2015a,b) have all been used to image the subsurface structure beneath SE Australia. Previous ambient noise tomography of Bass Strait used Rayleigh wave group velocity measurements (Pilia et al. 2015a,b). The limitation of this approach is that group velocities have a dependence on amplitude information, which can be distorted during processing (Yao et al. 2006). Yao et al. (2006) also demonstrated that the uncertainty associated with phase velocity measurements is much smaller compared to group velocity measurements. Previously, phase velocities proved to be virtually impossible to extract from Bass Strait data using conventional cross-correlation methods due to the high noise levels and complexity of the recovered signal (Pilia et al. 2015a). However, by using time-frequency domain phase-weighted stacking (tf-PWS; Schimmel et al. 2011), Pilia et al. (2016) successfully obtained phase velocity measurements which were then used in a large-scale regional study of 2-D azimuthal anisotropy. In this study, we also apply tf-PWS to substantially improve the signal-tonoise ratio (SNR) of cross-correlations and obtain phase velocity measurements. Based on these data, we use a robust Bayesian, hierarchical, transdimensional tomography technique to create a new high-resolution model of the 3-D shear wave velocity structure beneath Bass Strait from which we make inferences about crustal structure and consider the potential implications for the tectonic evolution of the region.

\section{GEOLOGY AND TECTONIC SETTING}

\subsection{Regional geology}

Fig. 1 shows a map of Bass Strait bathymetry and the surrounding geology. The oldest rocks in the SE Australia study area are found in western Tasmania and on King Island and are Mesoproterozoic in age (as old as $1430 \mathrm{Ma}$; Black et al. 2004; Halpin et al. 2014). However, in eastern Tasmania the oldest rocks are early Ordovician (Powell et al. 1993). An abrupt boundary between these two geological terranes follows the present day Tamar River, and it has been proposed to be the location of a crustal-scale discontinuity known as the Tamar Fracture System (Williams 1978). In Bass Strait, King Island to the northwest of Tasmania has similarly aged Proterozoic metasediments and intrusive geology to western Tasmania (Black et al. 2004; Berry et al. 2005; Calver et al. 2013). In contrast, the rocks of the Ferneaux Islands to the northeast of Tasmania are predominantly igneous intrusive rocks of Devonian age that have been emplaced into the Ordovician Mathinna Supergroup of eastern Tasmania (Black et al. 2005). Now submerged under Bass Strait, the Bassian Rise (Fig. 1, 'B.R.') may be a continuation of the Ferneaux Islands geology of extensive granites and granodiorites within Ordovician basement (Black et al. 2005; McClenaghan 2006).

Across Bass Strait to the north of Tasmania is Victoria, the southeast limit of mainland Australia. The two Palaeozoic orogenic belts which underlie this region can be further divided according to characteristic geology and deformation histories, which have led to a naming convention based on distinct zones (VandenBerg et al. 2000; Cayley et al. 2011; Fig. 1). The Lachlan Orogen includes the zones of Stawell, Bendigo, Melbourne and Tabberabbera, which are the main areas of interest in this study. The Stawell and Bendigo zones are both characterized by oceanic, oceanic backarc and arc material that has been accreted onto the edge of the evolving continent of Gondwana. The 2006 Victorian deep seismic survey across these zones provides evidence for stacked slices of mafic oceanic and metasedimentary rocks underlying metaturbidites (Cayley et al. 2011). The major difference between the zones is that the Bendigo Zone consists of a relatively large proportion of oceanic crust (VandenBerg 1999) thickened through crustal-scale imbrication, whereas the Stawell Zone, which contains more sedimentary material, is not as thick since it may have been obducted onto the Bendigo Zone (Vandenberg \& Stewart 1992; Cayley 2011). The boundary between these thinner and thicker terranes is the Avoca Fault. The western boundary of the Stawell Zone is the Moyston Fault, which also marks the western extent on the Lachlan Orogen (VandenBerg et al. 2000; Korsch et al. 2002; Miller et al. 2005; Cayley et al. 2011). Further east, the Melbourne Zone consists of a thick sedimentary sequence of Silurian-Devonian age. The nature of the lower crust on which these sediments were deposited is still debated. Two end-member models in this debate are (1) duplexed Cambrian oceanic crust or mafic material, similar to the Bendigo Zone (Gray \& Foster 1998; Fergusson 2003), and (2) an extension of thin Tasmanian Proterozoic-Cambrian continental crust - the Selwyn Block of Cayley et al. (2002). The eastern margin of the Melbourne Zone is generally thought to be the Governor Fault (VandenBerg et al. 2000), a northeast- to east-dipping fault that thrust Cambrian to Silurian rocks of the Tabberabbera Zone over younger rocks of the Melbourne Zone (Cayley et al. 2002). Adjacent to the Melbourne Zone, the Tabberabberan Zone is predominantly characterized by Ordovician turbidites overlying mafic oceanic basement (Crawford 


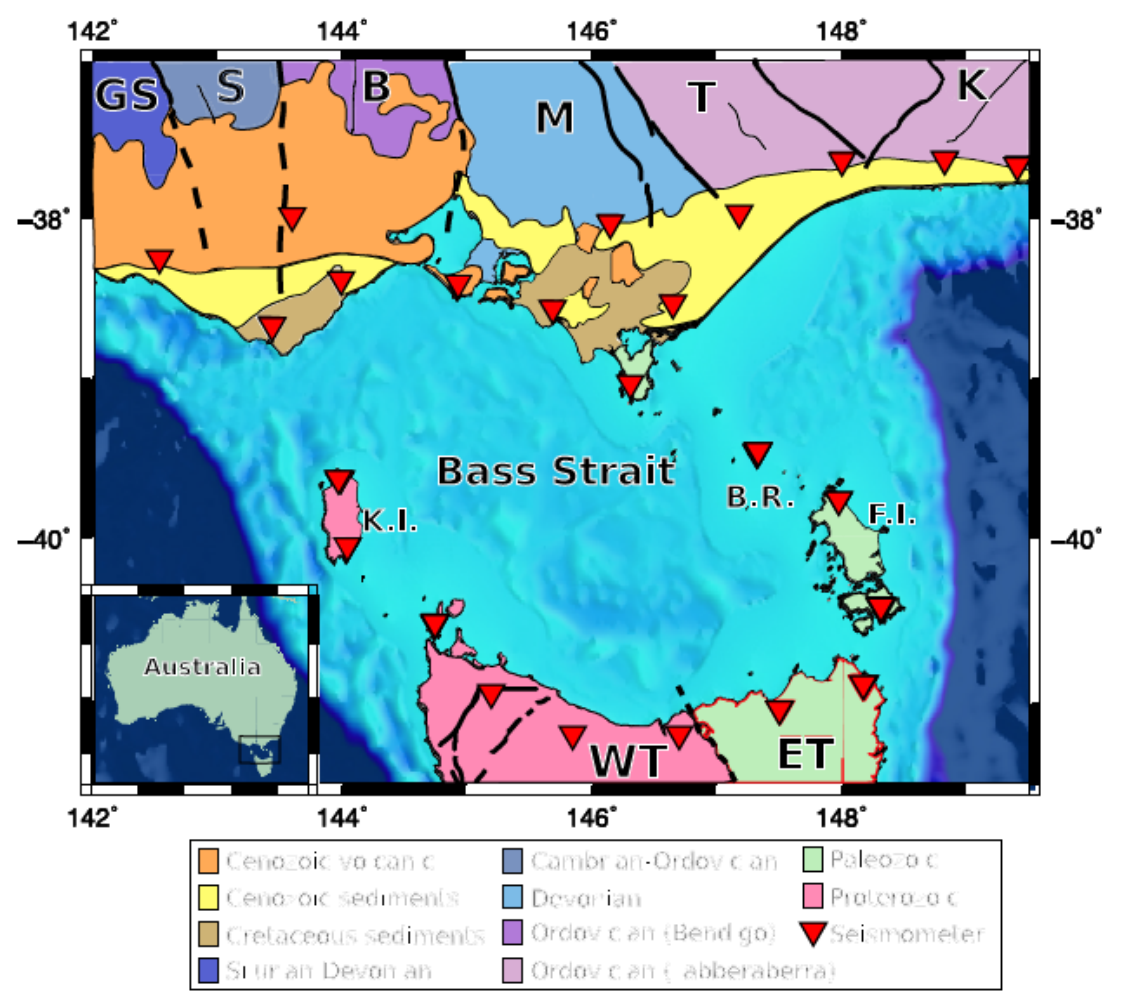

Figure 1. Study area, bathymetry of Bass Strait, seismometer network (red triangles) and location of Cenozoic volcanics and sediments which obscure deeper crustal structure. Surface geology and mapped faults modified from Geoscience Australia (2018). Black lines: surface faults; dashed black lines: possible continuations of mapped faults; GS: Grampians-Stavely Zone; S: Stawell Zone; B: Bendigo Zone; M: Melbourne Zone; T: Tabberaberra Zone; K: Kuark Zone; WT: West Tasmania Terrane; ET: East Tasmania Terrane; K.I.: King Island; F.I.: Ferneaux Islands; B.R.: Bassian Rise.

et al. 1984; VandenBerg et al. 2000). Interestingly, there is no evidence of Tabberabbera Zone detritus in the Melbourne Zone until the Early Devonian, despite the former being deformed in the Silurian (Moore et al. 2016). To the east of the Tabberabbera Zone is the Kuark Zone, which primarily consists of Ordovician metasediments, with Silurian-Devonian granites making up the remaining 10-15 per cent of the surface geology (VandenBerg et al. 2000). The Lucas Point Fault is thought to mark the boundary between the two zones (VandenBerg et al. 2000; Willman et al. 2002) and is mapped at the surface as a steeply west-dipping thrust fault with a throw estimated to be several kilometres (Orth et al. 1995; Ogden et al. 2016).

Between mainland Australia and Tasmania, beneath the waters of Bass Strait, lie three thick sedimentary basins, the Bass, Gippsland and Otway basins. These basins are all part of a failed branch of the southern margin rift system that began separating Australia from Antarctica in the Late Jurassic, with final breakup occurring at $\sim 65$ $\mathrm{Ma}$ (Norvick \& Smith 2001). The Bass Basin is underlain by an extensive series of NW-SE oriented half-grabens that developed during pulses of rifting from the Early Cretaceous to the Middle Eocene. A basin-wide accommodation zone that separates the Cape Wickham Sub-basin from the Durroon Sub-basin is termed the Chat Accommodation Zone (CAZ; Blevin 2003). The trend of the CAZ is approximately $\mathrm{N}-\mathrm{S}$ and its position is coincident with the northward projection of the Tamar Fault Zone of eastern Tasmania, suggesting fundamental basement control (Cayley et al. 2002). The Tasman rift system initiated ENE-WSW rifting along the eastern edge of Gondwana from $\sim 83 \mathrm{Ma}$, which propagated northwards past the Gippsland Basin during the early Campanian (Birch 1987; McPhail 2000; Hill et al. 2001). There is extensive evidence for the presence of volcanic material throughout the three basins. In the Bass Basin, wells and seismic reflection data both show extensive OligoceneMiocene volcanic rocks (Cummings et al. 2004; Meeuws et al. 2016), which coincide with distinct pulses of structural reactivation (Lennon et al. 1999). Additionally, Meeuws et al. (2016) reviewed the Cenozoic magmatism in onshore Tasmania and proposed that there is a timing relationship between the ages of the Tasmanian Cenozoic basalt and unconformities in the sedimentary sequence during the evolution of Bass Basin. In the onshore Otway Basin, there are outcropping extrusive rocks from the older and newer volcanic groups, aged $\sim 58-42 \mathrm{Ma}$ and $\sim 5-0 \mathrm{Ma}$ respectively (Price at al. 2003). Offshore, 2-D seismic reflection data reveal igneous rocks (of age $\sim 65-45 \mathrm{Ma}$ ) throughout the basin (Schneider et al. 2004; Holford et al. 2012). In the Gippsland Basin, the highest concentration of igneous rocks is in the northeast, covering an area of $\sim 300 \mathrm{~km}^{2}$ and has been dated as Campanian in age (83-72 Ma; Birch 1987). A secondary volcanic province covering an area of $\sim 200 \mathrm{~km}^{2}$ is in the southeast of the basin (Birch 1987) and the youngest known igneous rocks are $\sim 45 \mathrm{Ma}$ (McPhail 2000). Using seismic reflection data, O'Halloran \& Johnson (2001) identified igneous intrusive sheets that concentrate along major fault zones and appear to feed overlying extrusive centres. Close relationships between igneous rocks and large faults in the Gippsland Basin are also noted by Birch (1987) and McPhail (2000), who interpreted the northeastern igneous province to have been formed as the Tasman spreading centre passed the basin $(\sim 83-80 \mathrm{Ma})$. Eocene-Miocene inversion affected the Bass, Otway and Gippsland basins (Etheridge et al. 1991; Hill et al. 1995; Dickinson et al. 2001). Compressional reactivation within the Bass Basin was accommodated by rightlateral strike-slip deformation on $\sim \mathrm{N}-\mathrm{S}$ trending faults, and by 
localized inversion of NW-SE trending half-graben bounding fault systems (Cummings et al. 2004). Taylor \& Moore (2009) suggested that the shallow Otway Basin is caused by the presence of the shallow Selwyn Block and furthermore that the Cretaceous rift system along Australia's southern margin failed because of the presence of VanDieland.

\subsection{Tectonic model}

Cayley et al. (2002) primarily used aeromagnetic data along with evidence from outcrop geology to put forward the Selwyn Block model. They interpret magnetic anomalies in western Tasmania to extend $\sim \mathrm{N}-\mathrm{NE}$ across Bass Strait to the south coast of Victoria. This is used as evidence for the Selwyn Block as an extension of the ancient Tasmanian Proterozoic-Cambrian crust beneath the Melbourne Zone on mainland Australia. A deep seismic reflection profile beneath Victoria shows evidence of a multilayered crustal structure that appears to support the Selwyn Block model (Cayley et al. 2002, 2011). Expanding on this model, Cayley (2011) provided a new tectonic model of SE Australia which involves a Proterozoic, exotic microcontinent, which he termed 'VanDieland'. The microcontinent is comprised of the Selwyn Block, western Tasmania, and the surrounding submarine plateaus. After beginning hundreds of kilometres east of the eastern Gondwana margin, adrift in the paleoPacific as a consequence of Rodinia break-up, VanDieland began converging with Gondwana in the Cambrian during proto-Pacific subduction along the eastern margin of Australia. During this westdipping subduction, ophiolites were emplaced in western Tasmania. Northeast tectonic escape of VanDieland in the Early Ordovician is used to explain the present-day position of Tasmania outboard of the Delamerian orogen (Cayley 2011). Building on this idea, Moresi et al. (2014) used 3-D geodynamic models to demonstrate how an exotic microcontinent can become entrained in a subduction accretion margin, resulting in roll-back and the formation of an orocline. Their 3-D numerical simulation compares well with the model of Cayley (2011) in which the VanDieland microcontinent is accreted onto the edge of the east Gondwana margin resulting in the Lachlan Orocline (Moresi et al. 2014). Pilia et al. (2015b) provided support for the microcontinental model of Moresi et al. (2014), showing the extent of the Selwyn Block within the crust as predicted by surface geology and other geophysical data. Additionally, Pilia et al. (2016) presented azimuthal anisotropy tomography results from Rayleigh wave phase velocity data across mainland Australia. By comparing the orientation of magnetic fabric with the fast axis of anisotropy, they found a good correlation with the 3-D geodynamic model of Moresi et al. (2014) for the mainland.

\section{PREVIOUS GEOPHYSICAL STUDIES OF SE AUSTRALIA}

Ambient noise tomography has been used to probe the structure and formation of the Australian crust in a number of previous studies. The first of this kind was undertaken by Saygin \& Kennett (2010), who exploited Rayleigh wave group velocity dispersion for the period range 5-12.5 s and applied an iterative nonlinear tomographic inversion to produce group velocity maps. Despite their group velocities matching well with known basins and cratons, spatial resolution was $\sim 2^{\circ} \times 2^{\circ}$, resulting in a broad low-velocity zone beneath Bass Strait. Arroucau et al. (2010) also used Rayleigh wave group velocities, but from a much denser array in southeast Australia (WOMBAT) which at the time did not span Bass Strait.
Their group velocity maps from 2.5 to $20 \mathrm{~s}$ showed good correlation with sedimentary basins, but little correlation with major basement terrane boundaries. Young et al. (2011) used a very dense seismometer array located in north and east Tasmania for ambient noise tomography, with a station separation of $\sim 15 \mathrm{~km}$. Rayleigh wave group and phase velocity maps between 1 and $12 \mathrm{~s}$ showed that the neighbourhood of the Tamar Fracture Zone is characterized by low velocities. Bodin et al. (2012a) used their new hierarchical, Bayesian, transdimensional inversion scheme to account for uneven spatial distribution of data across the Australian continent. Using multiple group velocity data sets that sample the Earth at different scales, they generated a velocity map of the entire Australian continent. Despite covering Bass Strait, the resolution was low in this region since no BASS network data were used. In subsequent work Bodin et al. (2012b) used Bayesian statistics for Moho depth reconstruction in Australia, showing Moho depth to be $\sim 30 \mathrm{~km}$ under Bass Strait. The novel inversion scheme of Bodin et al. (2012a) was used by Young et al. (2013a) to produce a 3-D shear velocity model of Tasmania. The results showed an east-dipping, low-velocity zone around the Tamar River. The same inversion technique was also applied to the entire mainland southeast Australian WOMBAT data set to produce a 3-D shear wave velocity model of the crust (Young et al. 2013b). Interpretation of crustal features included an abrupt velocity transition as a signature of the east-dipping Moyston Fault at the edge of the Lachlan Orogen.

In order to better image the elusive link between mainland Australia and Tasmania, Pilia et al. (2015a) inverted ambient noise group velocity dispersion measurements from stations surrounding Bass Strait using the transdimensional method of Bodin et al. (2012a) for 3-D shear wave velocity structure. Pilia et al. (2015a) observed that the low velocity zones in the upper crust corresponded well with the Otway, Gippsland and Bass basins. They also interpreted a contiguous set of high velocity patches between the central Victorian coast and the northwestern Tasmanian coast as evidence of a link between the two regions, via the Selwyn Block/VanDieland hypothesis. However, other tomography studies in Victoria (Rawlinson \& Kennett 2008; Young et al. 2011; Young et al. 2013a) and Tasmania (Rawlinson et al. 2006; Young et al. 2013b) did not identify any similar features. Pilia et al. (2015b) extended their model of Bass Strait, using the same inversion method, to cover the entire region of southeast Australia spanned by the WOMBAT transportable seismic array. They found that the group velocity maps showed better correlation with mapped terrane boundaries compared to a shear wave velocity model. They suggested that this is due to the non-uniqueness associated with inverting group velocity for shear velocity. Pilia et al. (2015b) also identified a high velocity anomaly extending from Proterozoic northwestern Tasmania into mainland Australia as the Selwyn Block. It appears to have a much smaller extension into Victoria than other predictions of the Selwyn Block that are based on magnetics and outcrop geology.

Gunn et al. (1997) used the first available complete aeromagnetic coverage of the area, newly available gravity data, reflection seismic data, drill-hole information and outcrop geology to study the Bass Basin. They found that NE-SW tension along pre-existing basement structures produced three main sedimentary compartments that overlie accumulations of dense magnetic mafic material, which were likely produced by a mantle decompression process associated with crustal thinning. Morse et al. (2009) interpreted new aeromagnetic data to help delineate the structural architecture of the Bass Strait basins and underlying basement and the distribution of igneous rocks. McLean et al. (2010) modelled three gravity and magnetic profiles through the central and eastern part of the Melbourne 
Zone, where the top of basement was constrained to be $\sim 10-15 \mathrm{~km}$ deep. They concluded that the anomalies under the Melbourne Zone correlated with the Cambrian mafic-ultramafic complex of Tasmania, supporting the Selwyn Block model extending under mainland Australia. Moore et al. (2013) also used both gravity and magnetic data sets to conclude that the Selwyn Block model was a wellsupported hypothesis for SE Australia. Furthermore, Moore et al. (2016) used these data sets in conjunction with the information from geological outcrops to identify subdivisions across the VanDieland microcontinent, thus creating a new stratotectonic map of the region. Drummond et al. (2000) interpreted regional deep seismic reflection profiles off- and on-shore Tasmania to study the island's crust. Their findings for eastern Tasmania supported an extensional model where continental extension eventually led to the formation of very thin continental crust, likely related to Late Neoproterozoic extension recorded elsewhere in Australia (e.g. Gairdner dyke swarms, Zhao et al. 1994; Wingate et al. 1998).

\section{DATA AND METHOD}

Seismic data for this project come from a passive seismic array of 24, 3-component, broad-band seismometers (Fig. 1) deployed from 2011 to 2013. The network spans Bass Strait, with stations on the north coast of Tasmania, islands in Bass Strait (King Island, Deal Island and Flinders Island) and on the south coast of Victoria. Data were recorded for almost two and a half years across the array. The majority of seismic noise recorded by the array is from the Southern Ocean region surrounding Tasmania, which lies to the east, south and west. Microseisms are the main source of seismic noise from oceans, and are prominent in the period range $\sim 4-30$ s (LonguetHiggins 1950; Ardhuin et al. 2015). This is the main control on the SNR as a function of period.

Data recorded by the vertical component of each seismometer was used to extract Rayleigh wave signal. The cross-correlation procedure and subsequent velocity analysis follows the workflows described in Bensen et al. (2008) and Young et al. (2011). A preprocessing bandpass filter was applied between 0.025 and $0.5 \mathrm{~Hz}$ (2-40 s). The continuous data recordings were divided into $24 \mathrm{hr}$ lengths and after parameter testing for the optimum SNR the time window for cross-correlation was set to $30 \mathrm{~min}(1800 \mathrm{~s})$ with an overlap of 50 per cent $(900 \mathrm{~s})$. In this study phase, we apply timefrequency domain phase-weighted stacking or tf-PWS (Schimmel et al. 2011) to combine daily cross-correlations which attenuates incoherent noise and greatly improves SNR. For comparison purposes, cross-correlations were also stacked using linear, amplitude based stacking, including 1-bit normalization in order to mitigate the effects of deterministic sources such as earthquakes. The tfPWS results were compared to the linearly stacked waveforms and there was a striking improvement in the SNR of the tf-PWS signal (Fig. 2). The final cross-correlation functions are plotted as a function of inter-station distance in Fig. 3, and from this it can be seen that they are asymmetrical. This is because the ambient noise sources are not uniformly distributed and have a dominant location (i.e. the Southern Ocean rather than the Australian continent). In order to diminish the effect of non-uniformly distributed sources, the waveforms are made symmetrical by stacking the positive and negative time-lags of the cross-correlation. To exploit the dispersive nature of surface waveforms, frequency-time analysis is performed using multiple filter analysis to calculate the phase velocities associated with each period (Levshin \& Ritzwoller 2001). We measure phase velocity dispersion for periods ranging from 2-40 s using the image transformation technique described by Yao et al. (2006) and modified by Young et al. (2011 First, we band-pass filter the negative time derivative of the symmetric component of the green's function (EGFs) across a range of central periods. The width of this bandpass-filter has a linear dependence on the central period. Then, we create a velocity versus period (c-T) image on all the time-series of each filtered waveform. The c-T image is then used to automatically select the phase curve, as the $2 \pi$ phase ambiguity is usually straight forward to resolve. Curve picking is controlled by a user-defined average dispersion curve, based on period-velocity regions of highest energy. The phase velocity uncertainty estimate corresponds to the velocity window for which the amplitude of the energy peak is greater than 50 per cent of the maximum amplitude. Fig. 3(c) is an example of an automatically picked phase dispersion curve for station pair BA04-BA08 with an interstation distance of $191 \mathrm{~km}$. The final data set used for the inversion contains $\sim 100$ 200 measurements for each period, with the maximum number of measurements peaking at 217 for $6 \mathrm{~s}$ period (see Fig. $3 \mathrm{~b}$ for ray-path map at $6 \mathrm{~s}$ period).

\subsection{Inversion method}

We implement a two-stage method using a transdimensional, Bayesian inversion scheme first developed by Bodin \& Sambridge (2009). Subsequent extension of this method included the addition of a hierarchical component, whereby data noise becomes an unknown parameter to be quantified by a posterior probability density function (Bodin et al. 2012a). The first stage of our inversion scheme is to jointly invert phase velocity dispersion curves from all station pairs for period-dependent phase velocity maps. These maps are then sampled at regular points on a latitude/longitude grid to produce a set of pseudo-phase-velocity dispersion curves. In the second stage, these curves are inverted for 1-D shear velocity models, which are then combined to create the final 3-D shear velocity model.

In a transdimensional, hierarchical, Bayesian inversion scheme, each model is parametrized by Voronoi cells (Voronoi 1908) whose number, position and velocity are unknowns to be solved. Additionally, the level of noise in the data set is also treated as an unknown (in practice, the standard deviation of the noise). The complexity of the model is therefore driven directly by the spatial distribution of information contained in the data set. Transdimensional, hierarchical, Bayesian inversion eliminates the need for user defined, ad-hoc regularization parameters, thus making the approach more data-driven and robust than locally linearized methods (Bodin et al. 2012a).

To fully explore the model space, a large ensemble of models are generated (in the order of $10^{5}$ ) from which a posterior probability density function is produced (Green 1995). The ensemble of velocity models is generated by sampling the model space using the reversible-jump Markov chain Monte Carlo sampler (Metropolis et al. 1953; Hastings 1970; Green 1995). Predictions of forward traveltime and ray-path trajectory are implemented via the fast marching method (Sethian 1996; Sethian \& Popovici 1999; Rawlinson \& Sambridge 2004a, 2004b). After an initial 'burn-in' phase, the ensemble of remaining models converges asymptotically on the posterior probability distribution (Green 1995). This distribution is then used to extract robust structural information. In our case, we map each velocity model onto a regular grid and then take the average as being representative of the 'preferred model' and the standard deviation as an estimate of model uncertainty. 


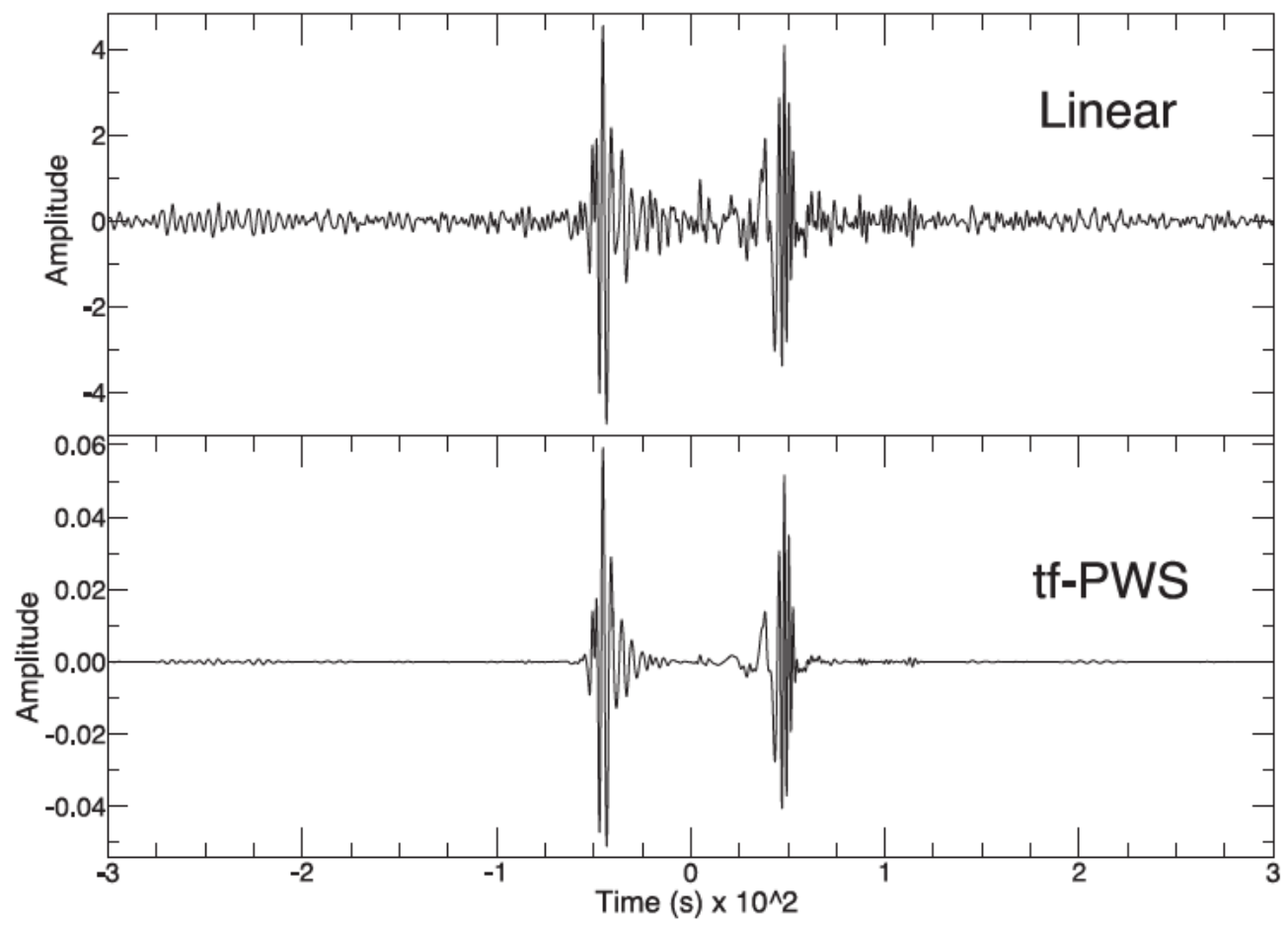

Figure 2. Example cross-correlation between a pair of stations, using linear versus time-frequency phase-weighted stacking (tf-PWS).
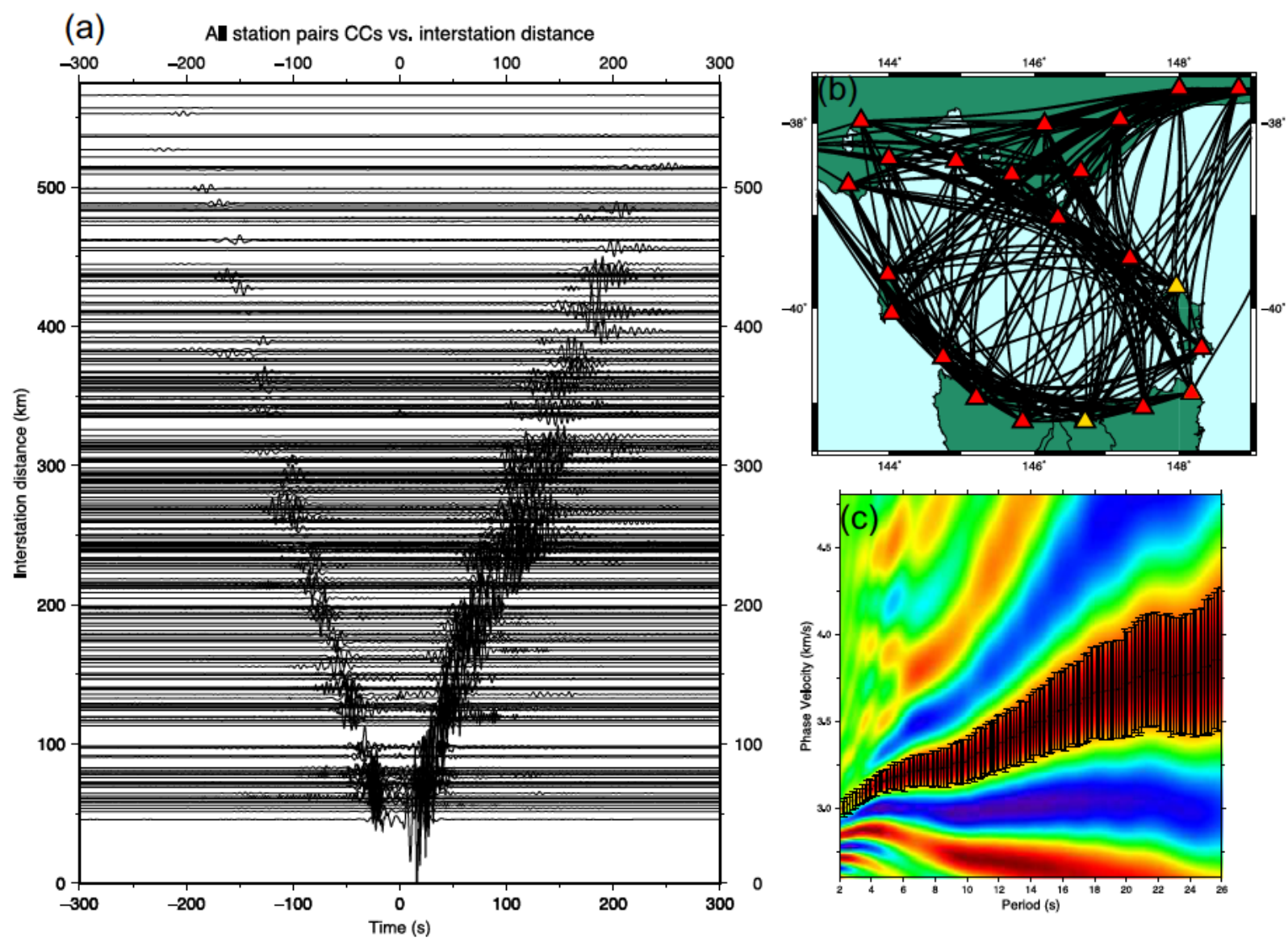

Figure 3. (a) Cross-correlations between all station pairs plotted against interstation distance; (b) ray-path coverage through 6-s-period phase velocity map; (c) phase velocity dispersion curve computed from cross-correlations between stations BA04 and BA08 (coloured orange) with an interstation distance of $191 \mathrm{~km}$. Solid black line and associated error bars denote the picks made at each period. 
In the first stage, period dependent phase velocity maps from $2-30 \mathrm{~s}$ at every even number were produced using the method outlined above. Out of 400000 total iterations, model unknowns were assumed to have converged after the first 120000 , which were discarded as the 'burn-in' phase. The remaining models were sifted by taking every 50th model, from which the average and standard deviation of velocities were calculated across a grid with regular spacing of $\sim 10 \mathrm{~km}$ in latitude and longitude. This inversion took $\sim 15 \mathrm{~min}$ for each period using 20 nodes on a cluster, each running 10 parallel processes. These 10 simultaneous and non-communicating Markov chains were run in parallel to fully optimize the sampling of model space. The minimum and maximum permitted number of Voronoi cells was 5 and 400 . Velocity limits for each period were $\pm 1.0 \mathrm{~km}$ $\mathrm{s}^{-1}$ around the average velocity for each period, found from first pass FMST tomography results. Phase velocity maps are shown at example periods 6, 12 and $26 \mathrm{~s}$ in Fig. 4, along with their associated standard deviation. The highest standard deviations tend to be found in regions of strong velocity gradient, such as around the edges of the sedimentary basins (e.g. in the centre of Fig. 4d) where low velocity sedimentary rocks contrast with higher velocity material outside the basin. The standard deviation patterns seen in our results are consistent with the 'uncertainty loops' identified by Galetti et al. 2015 in their study of the UK using a similar transdimensional scheme; in this scenario, the uncertainty in the location of the strong velocity contrast leads to a 'ring' of high uncertainty around the basin. The posterior distribution function for data noise parameter $\sigma$ is also displayed for each period (Figs $4 \mathrm{~g}-\mathrm{i}$ ). The parameter $\sigma$ effectively quantifies the data noise via the ability of the model to fit the data and accounts for both non-systematic observational and computational errors.

In the second stage, 2-D period dependent phase velocity maps are converted to a 3-D shear wave velocity model. The Bass Strait study area is discretized on a regular grid comprising 2100 points at $\sim 10 \mathrm{~km}$ spacing; at each of these points a pseudo-phase-velocity curve is created from the period-dependent output of the first inversion stage. For the pseudo-dispersion curve at each grid point, transdimensional, hierarchical, Bayesian inversion is applied to generate an ensemble of models where in this case the number, position, thickness and velocity of layers in a 1-D model are unknowns. As before, a posterior probability distribution is generated for each of the unknowns, from which an average and standard deviation are obtained. Subsequent interpolation between each 1-D model creates a continuous 3-D shear wave velocity model. The forward problem of predicting dispersion curves in the 1-D inversion is done using the DISPER80 code (Saito 1988). A major advantage of using this two-stage methodology is that standard deviations from the initial 2-D inversions are carried forward to the 1-D inversion stage. This ensures that noisy measurements (i.e. large standard deviation values) will not unduly influence the final solution. For each of the 2100 pseudo-phase-velocity dispersion curves, a total of 180000 model iterations were produced with 80000 discarded as 'burn-in'. Velocity was permitted to vary between 2.0 and $5.0 \mathrm{~km} \mathrm{~s}^{-1}$, and the total number of layers between 2 and 30 . The average and standard deviation of all 1-D models is used to define the final 3-D solution model and its associated uncertainty.

\subsection{Synthetic resolution tests}

To assess the reliability of velocity structures produced by the 2-D Bayesian inversion method, we performed a resolution test based on synthetic data. In order to illustrate the potential recovery of velocity discontinuities and structure of different scales, we constructed a synthetic velocity model that contains a variety of features (Fig. 5). Gaussian noise with a standard deviation equal to $1 \mathrm{~s}$ is added to the synthetic data to simulate uncertainties associated with the observational data set (e.g. picking of phase arrival time as a function of period). The maximum perturbation of the synthetic velocity anomalies is $\pm 0.4 \mathrm{~km} \mathrm{~s}^{-1}$. By using the identical source-receiver path configuration as the observational data set at $6 \mathrm{~s}$ period, we predict traveltime residuals for the input structure shown in Fig. 5. The inversion is then carried out using the Bayesian transdimensional scheme and the results are compared to those obtained with an iterative nonlinear inversion technique. This involved the use of the Fast Marching Surface-wave Tomography (FMST) package (Rawlinson et al. 2008). In FMST, parameters such as grid resolution, damping and smoothing are required to be user-defined. Throughout the study area, the input structures are generally better recovered by the Bayesian method, compared to the linearized inversion scheme (Fig. 5); this is despite the fact that the parameterization used for the linearized scheme matches that used to describe the synthetic structure, which means that it has favourable pre-conditioning. Relatively sharp velocity discontinuities are not well retrieved with the linear approach, which uses globally imposed smoothing and damping parameters. On the other hand, in the Bayesian method, the averaging process of the spatially varying Voronoi cells over thousands of models produces a smoothness directly controlled by the data itself. In order to show the high dependence of the linearized inversion model on the choice of damping and smoothing parameters, we present three different examples with different values (Fig. 5). As expected, when damping and smoothing are set to larger values major details such as strong velocity variations and multi-scale structure are lost; conversely, when they are set to smaller values, spurious small-scale structures are introduced. It is clear that the Bayesian inversion approach produces the most robust results, while the use of conventional ad hoc regularization (damping and smoothing in this case) strongly influences the results, and patterns of anomalies are dictated more by the restrictions of the method than the information contained in the data.

In order to investigate the reliability of the second stage, in which pseudo-phase-velocity curves are inverted for 1-D shear velocity models, we perform another synthetic test. A four-layer crustal shear velocity profile was designed as the synthetic input to test the transdimensional, hierarchical, Bayesian inversion's recovery ability (dashed line, Figs 6a and b). A synthetic phase velocity curve was predicted using the DISPER80 code (Saito 1988), with Gaussian noise with a standard deviation of $0.2 \mathrm{~km} \mathrm{~s}^{-1}$ added to simulate data uncertainty. This dispersion curve is then inverted for a 1-D shear velocity model using transdimensional, hierarchical, Bayesian inversion and the results are shown in Fig. 6. The quality of the recovered 1-D shear velocity model is generally good; this can be clearly seen by the agreement of the probability density plot and its mean with the input model (Figs 6a and b). The largest inconsistencies between the synthetic and recovered model occur at the velocity discontinuities. The posterior probability distribution for the number of layers in the recovered model (Fig. 6d) shows that the inversion peaks correctly at four layers. Considering that surface waves, and hence phase velocity dispersion, are not sensitive to sharp discontinuities, the fact that the mean solution model produces a smoothed version of the input model is hardly surprising. In this case, the surface waves cannot distinguish between an interface at $5 \mathrm{~km}$ depth and $10 \mathrm{~km}$ depth, and hence sees a relatively rapid increase in velocity, which may be why the probability of a 

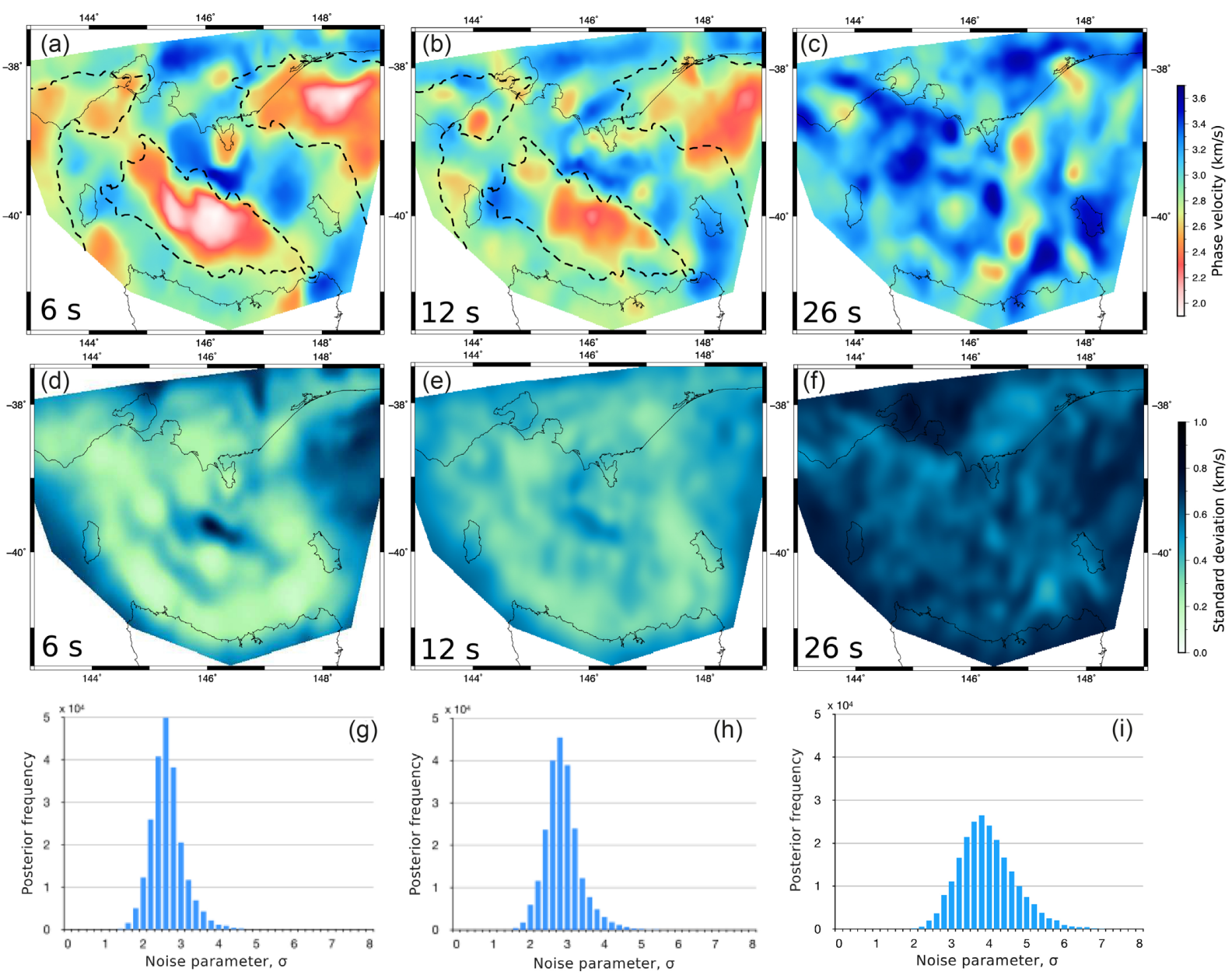

Figure 4. Period-dependent phase velocity maps for 6, 12 and $26 \mathrm{~s}$ period (a-c) along with their associated standard deviation maps (d-f) and posterior probability density function of data noise $(\mathrm{g}-\mathrm{i})$.

discontinuity plot peaks at a depth of around $7.5 \mathrm{~km}$. The transition to upper mantle velocities at $20 \mathrm{~km}$ is likewise not detected as a sharp velocity discontinuity but rather as a smooth transition to higher wave speed. Thus, the smooth velocity variations with depth seen in our results from the BASS data set are not a function of any imposed parameterization.

\section{RESULTS AND INTERPRETATION}

Figs 7 and 8 show the 3-D crustal structure beneath Bass Strait in a series of horizontal and vertical slices taken from the final tomographic solution model. Significant velocity anomalies that will be interpreted are numbered on the maps in Fig. 7. At depths greater than $\sim 30 \mathrm{~km}$, the model reliability becomes poor since information about deeper structures in the crust and upper mantle is lost as the number of ray paths sampling these regions decreases with depth. We use the standard deviation of the model ensemble, computed at each individual grid point in latitude and longitude, as an estimate of uncertainty (Figs 7d-f). Regions of high standard deviation can generally be correlated with a lack of path coverage or lack of crossing paths (e.g. the Gippsland Basin in the NE of the model). Low-velocity basins tend to be avoided by first-arriving paths which can also result in elevated uncertainties.
Figs 7(a) and (b) show horizontal slices at 5 and $10 \mathrm{~km}$ depth. Velocities are as low as $2.0 \mathrm{~km} \mathrm{~s}^{-1}$ in sedimentary basins (particularly Bass and Gippsland), but for the purposes of visualization the colour scale range for the model is $2.4-4.1 \mathrm{~km} \mathrm{~s}^{-1}$. The three sedimentary basins in Bass Strait, the Otway Basin (anomaly 1 and 2), the Gippsland Basin (anomaly 4) and the Bass Basin (anomaly 5) are clearly imaged. They are characterized by shear wave velocities in the range $2.0-2.9 \mathrm{~km} \mathrm{~s}^{-1}$. Sediment thickness mapping shows sedimentary material up to $14 \mathrm{~km}$ thick in the Central Deep part of the Gippsland Basin (Power et al. 2001) and between 10 and $12 \mathrm{~km}$ in the central Bass Basin (Teasdale et al. 2001). Low shear wave velocities from 2.0 to $2.6 \mathrm{~km} \mathrm{~s}^{-1}$ are observed in our velocity model in the region of the Gippsland Basin extending to $\sim 12-14 \mathrm{~km}$ depth (Fig. 8d) and the Bass Basin extending to $\sim 10-12 \mathrm{~km}$ depth (Fig. 8g), confirming that we are likely imaging the sedimentary deposits in these basins. Two distinct low velocity anomalies (Figs 7a and $b$, labelled 1 and 2) of $\sim 2.8 \mathrm{~km} \mathrm{~s}^{-1}$ correspond to the areas of the Inner Otway and Torquay sub-basins. A sediment thickness map produced for the Otway \& Sorell Basins (Teasdale et al. 2002) indicates that there is between 5 and $8 \mathrm{~km}$ of sediment in the region of the Otway Basin covered by our velocity model. This is almost half of the thickness observed in the other two basins in Bass Strait. This may explain why the $5 \mathrm{~km}$ depth slice through the velocity model (Fig. 7a) does not show the same low shear wave speeds in the Otway Basin compared to those in the Bass and Gippsland 

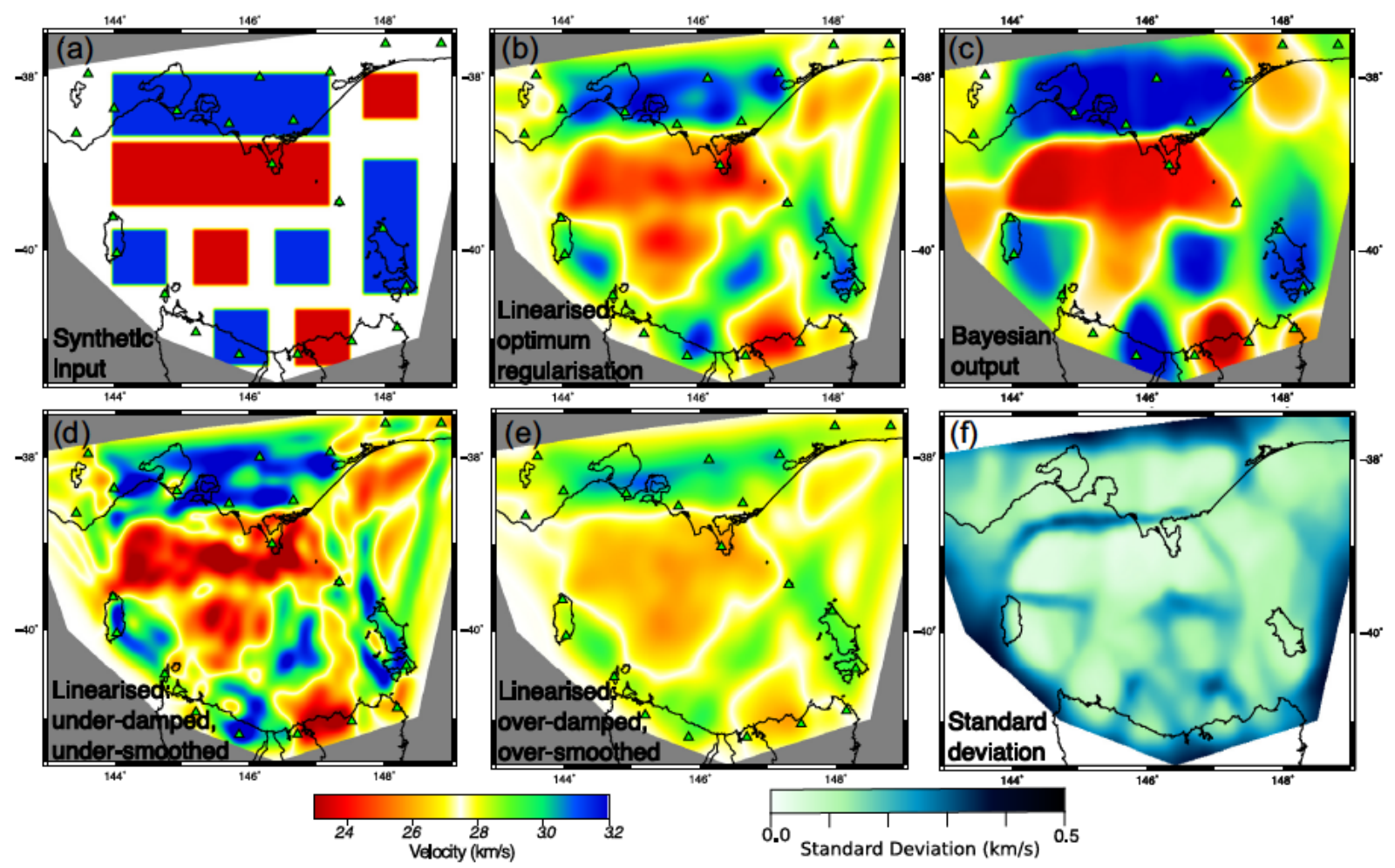

Figure 5. Synthetic resolution test for $6 \mathrm{~s}$ phase velocity map. (a) Synthetic velocity model to be recovered; (b, d, e) recovery test results for the linearized inversion with different damping and smoothing values; (c, f) recovery test results for transdimenional, Bayesian method with associated standard deviation of recovered model.

basins. However, the two sub-basins (Inner Otway and Torquay subbasins) still appear to be visibly defined as two distinct low velocity patches.

A velocity contrast between east and west Tasmania appears in both the shallower and deeper crust (Figs 7a and c). At $5 \mathrm{~km}$ depth, west Tasmania features higher velocities than the east, whereas at $25 \mathrm{~km}$ depth, east Tasmania exhibits higher velocities. A lowvelocity anomaly labelled '7' in Fig. 7(b) corresponds to the location of the Tamar River, which is a large NE trending feature in Tasmania. This low velocity anomaly appears to directly overlie a small area of very high velocity $\left(>4.0 \mathrm{~km} \mathrm{~s}^{-1}\right.$ ) below $20 \mathrm{~km}$ depth (labelled 11 in Fig. 7c). This feature can be seen clearly on a vertical slice through northern Tasmania (Fig. 8h), with different crustal structures seen on either side of it.

An interesting linear feature appears on horizontal slices at depths $>15$ km (labelled ' 8 ' in Fig. 7c). This linear feature trends NW-SE, almost extends across the entire Bass Strait and is characterized by velocities $>3.8 \mathrm{~km} \mathrm{~s}^{-1}$. The lineament lies beneath the low velocities of the Otway and Bass Basins and may be interpreted to extend to just offshore northern Tasmania and/or to the Tamar River. Alternatively, it may terminate in the CAZ at $\sim 146.5^{\circ}$, where there is a distinct $\mathrm{N}-\mathrm{S}$ trending velocity discontinuity. Velocity anomaly '10' (Fig. 7c) is centred on Flinders Island where high velocities persist throughout the crust (Figs $8 \mathrm{~d}$ and $\mathrm{g}$ ). This anomaly is defined by velocities $>3.9 \mathrm{~km} \mathrm{~s}^{-1}$ in a structure that appears to have an apparent dip westward (Fig. 8g).

In regions of the model where the velocity gradient changes rapidly in the crust, we assume this reflects a change in rock composition. Fig. 9(a) shows a vertical slice through our 3-D shear velocity model which largely crosses onshore mainland Australia in Victoria, so we attempt to correlate the known geological terranes (Stawell,
Bendigo, Melbourne, Tabberabbera and Kuark zones; Fig. 1) with the observed velocity structures. Our interpretation is assisted by previous studies of the structure of the area, including the structural profiles proposed by Cayley et al. (2011; Fig. 9c) and Gray (1997; Fig. 9d), noting that they are located some distance north of our cross-section (see Fig. 9e). Three crustal scale faults which bound the terranes have been superimposed on Fig. 9(a) from the deep seismic reflection profile of Cayley et al. (2011; red dashed lines). The black dashed lines show our suggested positions of terrane bounding faults along our shear velocity cross-section. The Moyston Fault Zone at the western boundary of the Stawell Zone is thought to be a large east-dipping structure. The Avoca Fault Zone may sole out onto this surface and extend below the Bendigo Zone (Figs 9c and d; Gray 1997; Cayley et al. 2011), however it is unclear from our shear velocity model how far it continues through the crust in this location. Our velocity model shows a distinct, crustal-scale, east dipping wedge of higher velocity under the Stawell and Bendigo zones in the hanging wall side of the Moyston Fault, which may be due to the presence of Cambrian mafic meta-igneous material that is thought to underlie the area (Cayley et al. 2011). The footwall rocks of the Grampians-Stavely Zone to the west of the Moyston Fault are very weakly metamorphosed sedimentary rocks, which can explain the relatively lower velocities on that side of the fault zone (VandenBerg et al. 2000). The Avoca Fault Zone is the bounding fault between the Stawell Zone and thicker crust of the Bendigo Zone; its location and dip are well known from surface mapping, and in Fig. 9(a) it appears to be marked by some change in velocity gradient. At the other edge of the Bendigo Zone at $\sim 145^{\circ}$ lies the Heathcote Fault Zone. Extrapolation of its known location and geometry at the surface to deeper crust appears to match with changes in velocity in Fig. 9(a). 

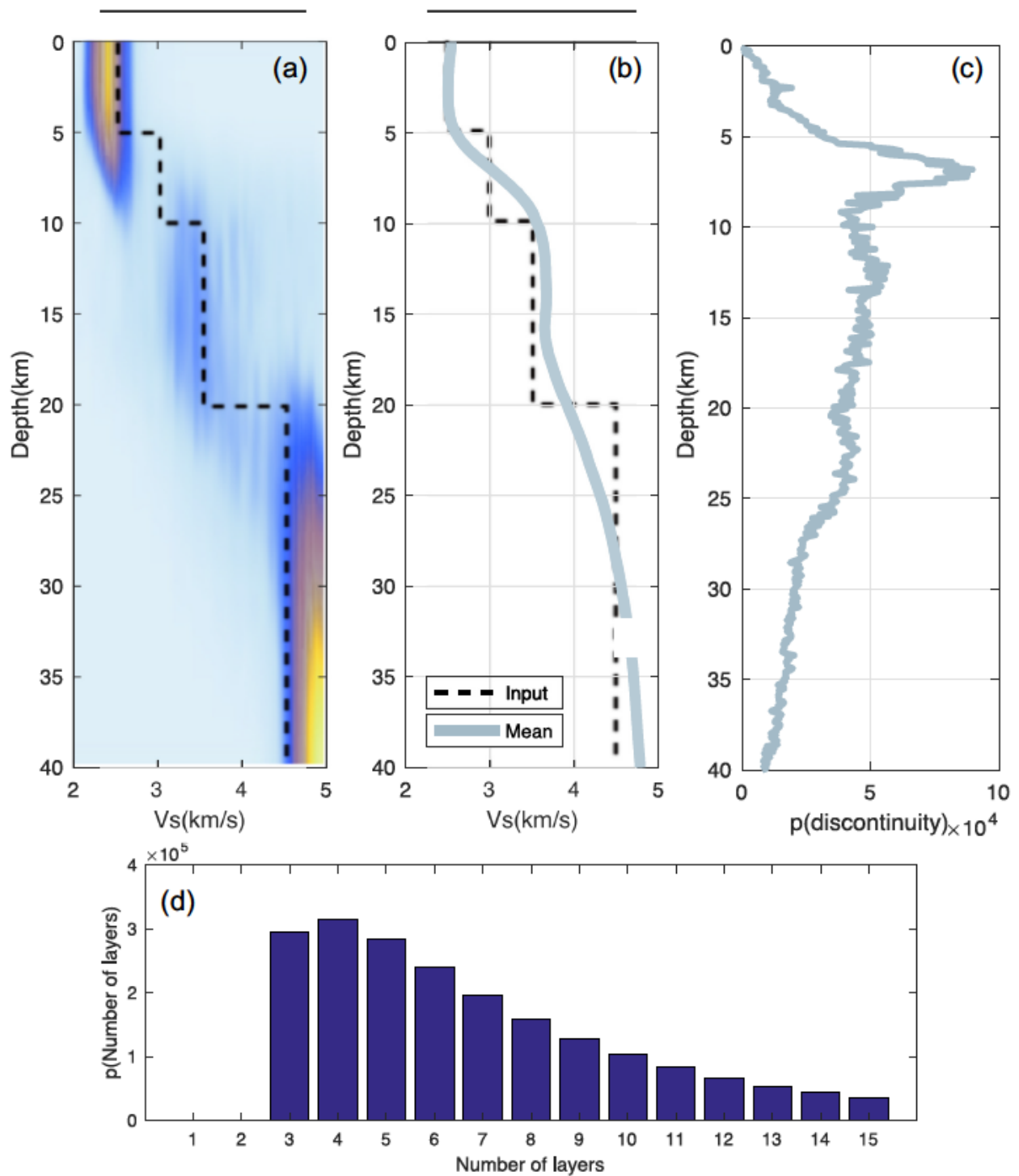

Figure 6. Results of a synthetic recovery test for 1-D crustal shear velocity structure. Black dashed line denotes the input model that we attempt to recover. (a) Probability density plot; yellow is high probability and blue is lower probability, (b) mean of the recovered velocity distribution, (c) probability of a discontinuity as a function of model depth, (d) histogram of posterior distribution on the number of layers.

The Governor Fault Zone marks the complex tectonic boundary between the Melbourne and Tabberabbera zones (VandenBerg et al. 2000; Cayley et al. 2011). Fig. 9(a) is interpreted to show the Governor Fault Zone as an east-dipping surface which marks a change at depth from higher velocities in the west to lower velocities in the east. Centred around $147^{\circ}$ is a high velocity anomaly $\left(>3.8 \mathrm{~km} \mathrm{~s}^{-1}\right)$ at depths $>15 \mathrm{~km}$. This anomaly lies to the east of the Governor Fault and is clearly revealed in the $25 \mathrm{~km}$ depth slice (labelled ' 9 ' in Fig. 7c). We speculate that it corresponds to a subtle deep magnetic high observed in the same location on Fig. 10(c), which may reflect the presence of mafic volcanic rocks up-thrust from the base of the Tabberabbera Zone (Vandenberg et al. 2000).

\section{DISCUSSION}

By inverting phase velocity dispersion measurements extracted from ambient noise cross-correlations using a Bayesian, hierarchical, transdimensional inversion scheme, we have created a new 3-D shear wave velocity model which we now discuss in detail. In order to interpret this model of Bass Strait in a wider context, it is compared to a variety of complementary data sets, as well as previous studies. The shear velocity model is compared to gravity, magnetic and geological data and previously proposed tectonic models are considered in relation to our results.

The three sedimentary basins in Bass Strait (the Bass, Otway and Gippsland basins) are outlined in Fig. 10(a) with basin contours at $\sim 1500 \mathrm{~m}$ and $\sim 6000 \mathrm{~m}$, denoting the extent of the basin and its deepest depocentres, respectively. These contours are from the 'Structurally Enhanced view of Economic Basement Project' (SEEBASE ${ }^{\mathrm{TM}}$; Teasdale et al. 2001), which used large volumes of data (including structural and kinematic interpretation, geophysical 


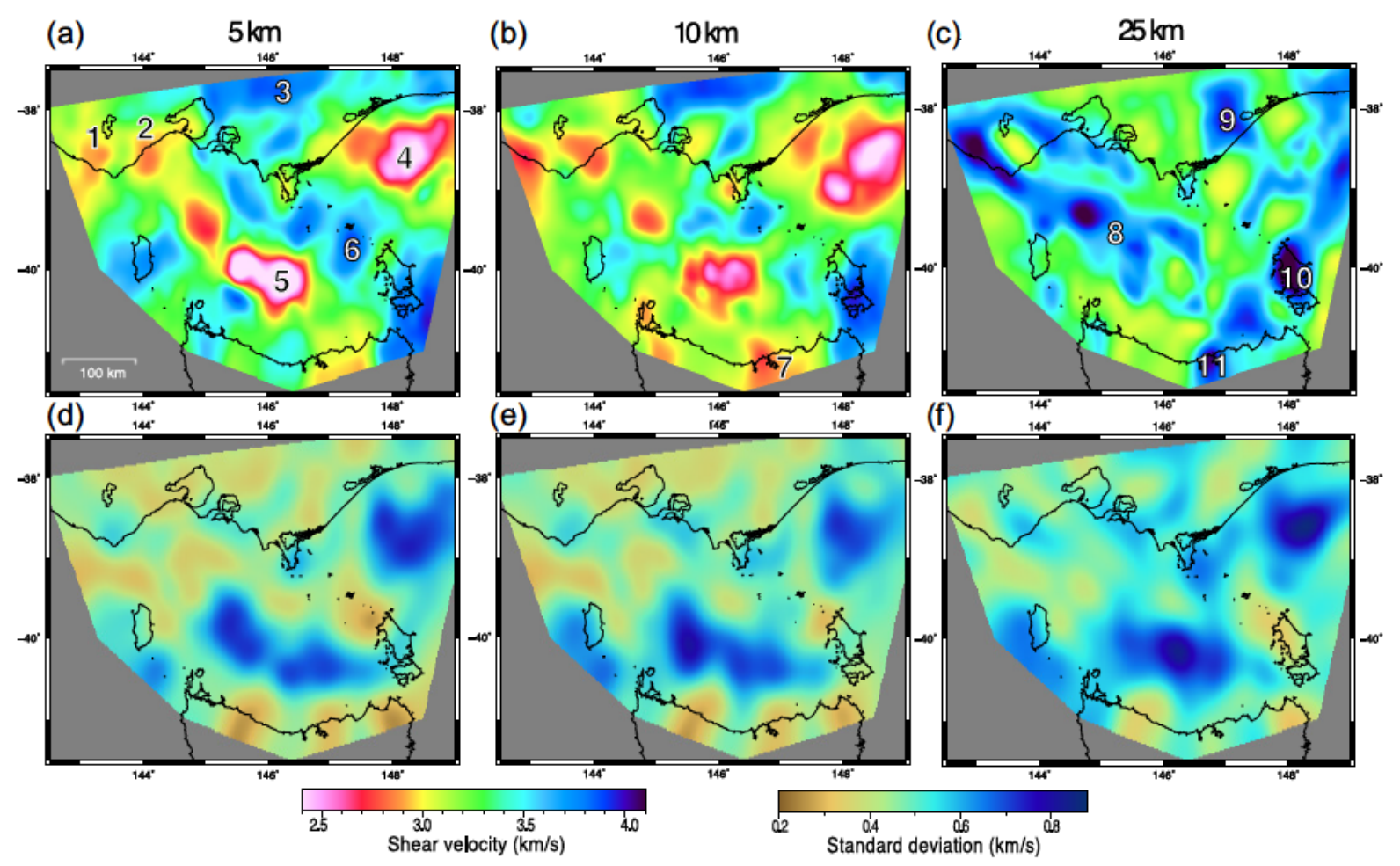

Figure 7. (a-c) Horizontal slices through the 3-D shear wave velocity model at depths of 5, 10 and $25 \mathrm{~km}$. (d-f) Standard deviation of the velocity model at corresponding depths of 5, 10 and $25 \mathrm{~km}$. Numbers superimposed on the plots denote locations that are discussed in the main text.

modelling and seismic and well data calibration) to help constrain sediment thickness beneath Bass Strait. Previous tomographic images of the Bass Strait basins have generally been less detailed when imaged as part of the whole continent (e.g. Saygin \& Kennett, 2010, 2012; Bodin et al. 2012a). By using data from the within and at the margins of Bass Strait, we reveal more detail in our study. Our new 3-D model shows low-velocity zones that are well matched to the known basin outlines, and there is also a very good match to the regions of maximum sediment deposition (Fig. 10a). These results help to confirm that our model is a robust and reliable source of information on crustal velocity structure.

A number of fault zones have been interpreted on our 3-D shear wave velocity model which we can compare to previous studies. The Moyston, Avoca, Heathcote and Governor fault zones located in Victoria have been identified on seismic reflection profiles (Cayley et al. 2011). The Avoca Fault is interpreted as a west-dipping, listric reverse fault that intersects the Moyston Fault at a depth of about $22 \mathrm{~km}$ (Cayley et al. 2011), which our model broadly agrees with. It is also in agreement with the west-dipping Heathcote Fault, which Cayley et al. (2011) extend down to the Moho. Consistent with their finding, our shear wave velocity model suggests that it does indeed extend to at least $30 \mathrm{~km}$ in depth (Fig. 9a). We see evidence for eastand west-dipping velocity features which may be signatures of the Mt. Wellington and Governor fault zones respectively at $\sim 147^{\circ}$ at the surface, which corresponds to an area blanketed by Cenozoic sediments (Fig. 1). The deep seismic reflection profile of Cayley et al. (2011) does not extend close enough to this area to make a comparison. However, the MWFZ and GFZ locations do correspond well with a southeastward projection of the known fault traces from geological mapping (Fig. 1).

In the Melbourne Zone, there is a wedge of relatively high velocity material in the upper crust that thins towards the east (Fig. 9a). This is in contrast to the lower velocities in the surrounding upper crust of the Bendigo Tabberabbera zones, which have a much greater covering of Cenozoic/Cretaceous sediments (the Fig. 9a cross-section spans the northernmost Otway and Gippsland basins). The surface geology of the Melbourne zone is predominantly Devonian sediments/metasediments with intruded Upper Devonian granites. Although not visible in the seismic model due to resolution constraints, they likely affect the tomographic model by increasing the average velocities that we observe (it has been observed elsewhere that granite intrusions in the upper crust tend to increase average seismic velocities e.g. Flecha et al. 2006). In particular, the crosssection intersects the Lyserfield and Tynong granite plutons (e.g. Richards \& Singleton 1981; Rossiter 2003; Clemens et al. 2016) at $145.2^{\circ}-146.0^{\circ}$.

In Tasmania, the velocity 'inversion' between the shallow and deep responses of eastern and western Tasmania may be explained by their composition. The Rocky Cape, Burnie and Tyennan Group rocks of the west Tasmania terrane are thought to be underlain by metasedimentary rocks (Black et al. 2004; Black et al. 2010; Chmielowski \& Berry 2012; Moore et al. 2016) whereas the east Tasmania terrane may be underlain with basaltic volcanic rocks (Moore et al. 2016). Moreover, basaltic volcanic rocks are present in the Smithton Basin, the upper sequence of western Tasmania, in the area that corresponds to the highest velocities in the west (see Fig. 8h). We expect higher shear wave speeds in areas dominated by mafic volcanics, so our new velocity model corresponds well with the proposed composition of the crust in northern Tasmania.'

We identify the Tamar River as the location of a low-velocity anomaly directly overlying a high-velocity anomaly. Young et al. (2013a) used ambient noise data and transdimensional, hierarchical, Bayesian inversion to develop a shear wave velocity model of Tasmania down to $15 \mathrm{~km}$ depth. They also found an east-dipping, 
(a)

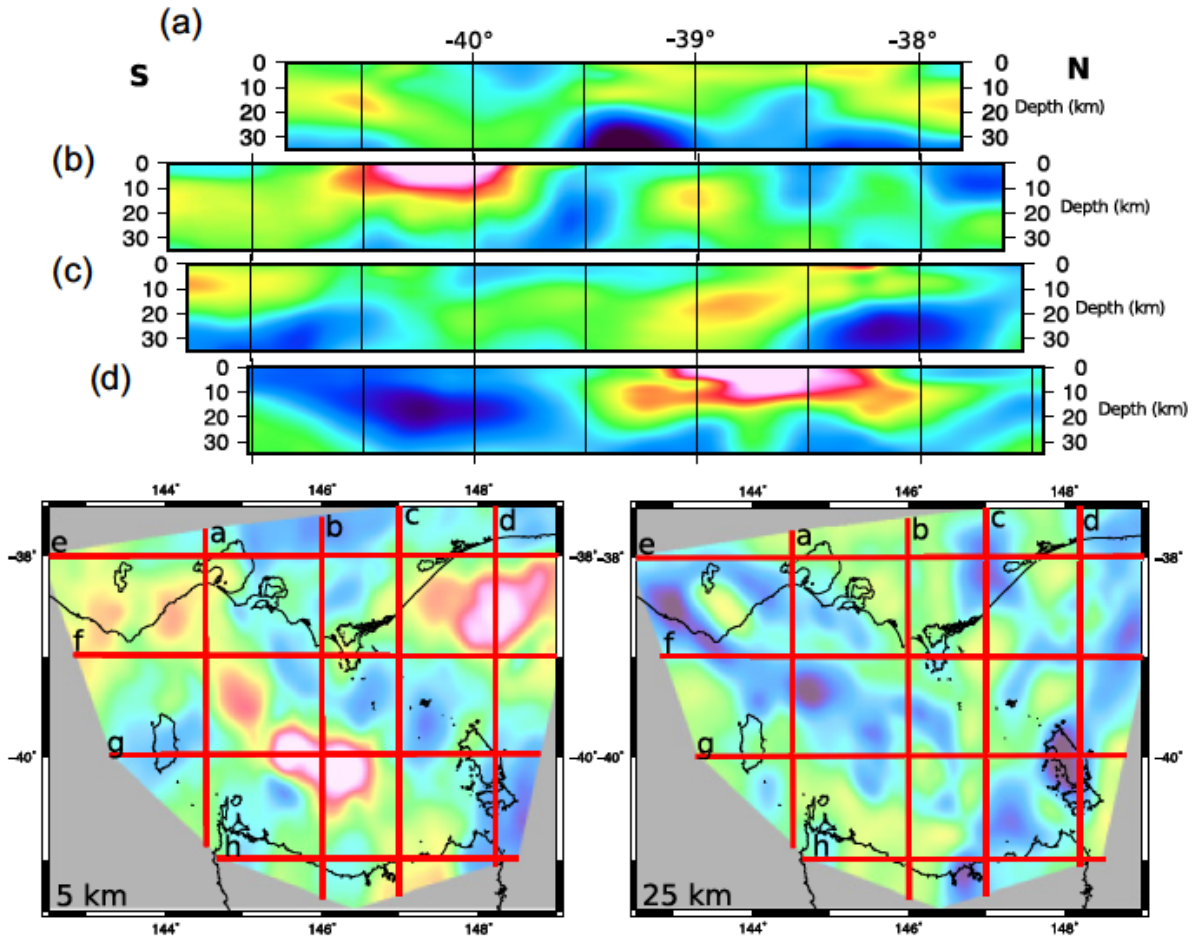

(e)

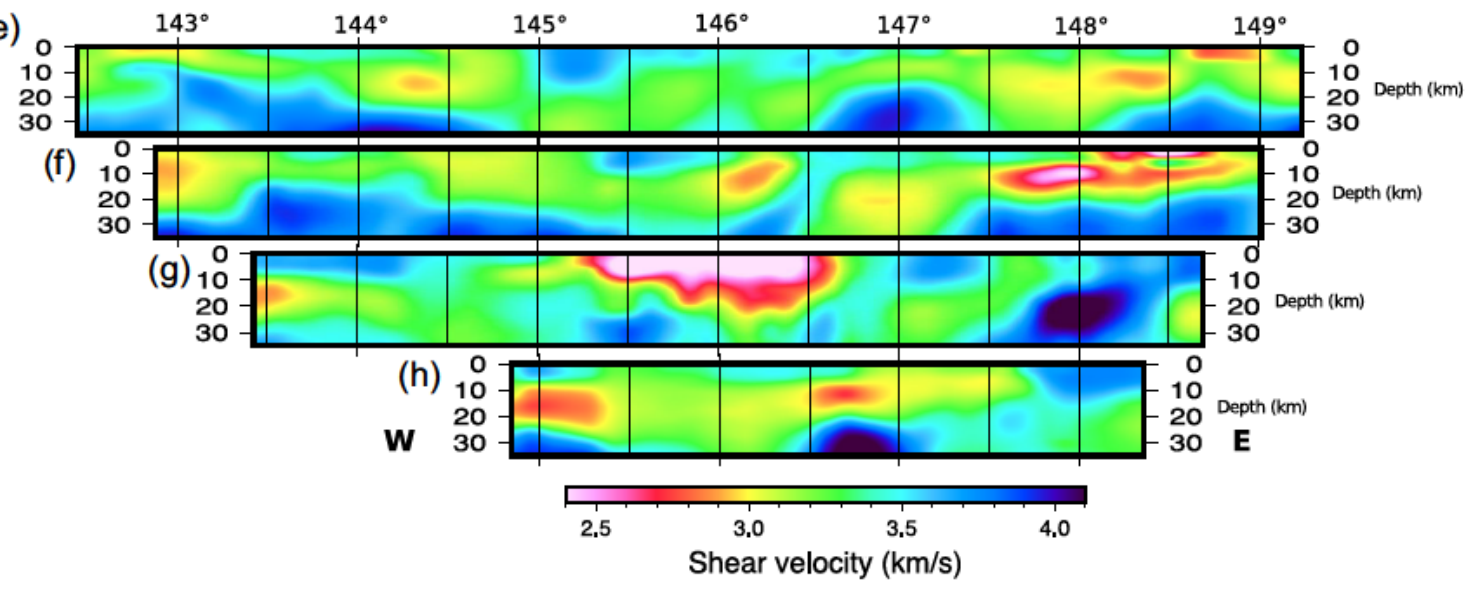

Figure 8. Vertical slices taken through the 3-D shear velocity model. The location of the transect of each depth section is shown as a red line on the maps for reference.

low-velocity lineament in the vicinity of the Tamar River that extended to at least the depth of their model. Young et al. (2013a) proposed that this represented the Tamar fracture system and was the result of deformation associated with the shortening, thickening and accretion of oceanic crust along the eastern margin of Tasmania during the early mid-Palaeozoic, coupled with intrusion of granites in the Devonian. We show that this anomaly reverses polarity below $\sim 20 \mathrm{~km}$ to become a very high velocity anomaly in the lower crust below the Tamar River. There are extensive outcrops of Jurassic dolerite along the Tamar River valley (Hergt et al. 1989) and we speculate that the elevated shear velocities described above may be related to these igneous intrusions in the crust. The overlying lower velocities are likely due to more recent sediment deposits from the Cretaceous to Cenozoic.

To put our new 3-D shear wave velocity model into the context of tectonic evolution in SE Australia, we consider whether evidence can be found for the Selwyn Block model. The extent of the Selwyn Block defined by Pilia et al. (2015b) is shown as a red dashed line in Fig. 10. They used ambient noise tomography of Rayleigh wave group velocities to estimate the Selwyn Block boundary at $25 \mathrm{~km}$ depth. This boundary matches almost perfectly to a number of strong velocity gradients in our new shear velocity model (Fig. 10b). Most notably, in Tasmania and northwards into Bass Strait, the dashed red line corresponds directly to an abrupt change from lower velocities in the west to higher velocities in the east. However, on mainland Australia there is less correlation between our model and the Selwyn Block boundary as defined by previous ambient noise tomography. In support of the Selwyn Block model, Moore et al. (2016) suggested that the Melbourne Zone is underlain by the Rocky Cape Zone (a Meso-Neoproterozoic West Tasmania terrane). Our results at $25 \mathrm{~km}$ depth indicate very similar shear wave velocities/structures in northwest Tasmania and in the vicinity of the Melbourne Zone, which support their conclusion.

A NW-trending zone of high velocities in the lower crust extends into Bass Strait and across the proposed location of the Selwyn 

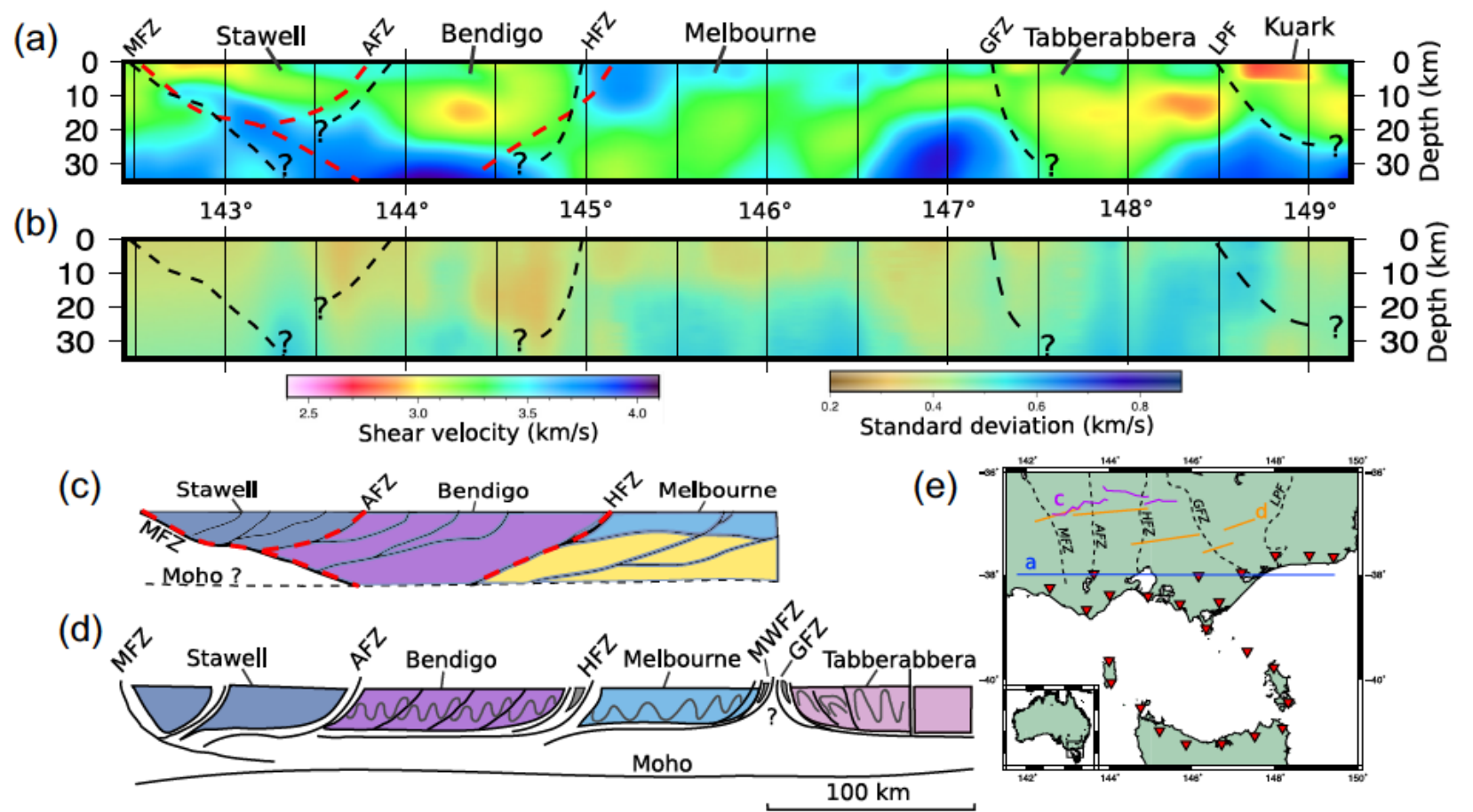

Figure 9. (a,b) Vertical shear velocity and standard deviation slices taken at $-38.07^{\circ}$ latitude. Black dashed lines mark possible velocity discontinuities/structures. Features and velocity anomalies mentioned in the text are labelled. Schematic structural west-east profiles of the Lachlan Orogen after (c) Cayley et al. (2011) and (d) Gray (1997). The profile of Cayley et al. (2011) is from deep seismic reflection profiles (measured in two-way time) and the red dashed faults from it are superimposed on (a). Location map of cross-sections (e). MFZ: Moyston Fault Zone; AFZ: Avoca Fault Zone; HFZ: Heathcote Fault Zone; GFZ: Governor Fault Zone; LPF: Lucas Point Fault.

Block. This zone may tentatively be extended to offshore NE Tasmania. It is located almost directly below the failed rift basins, the Inner Otway and Bass Basins. The high shear velocity zone in our model is defined by velocities of $\sim 3.8 \mathrm{~km} \mathrm{~s}^{-1}$ at $25 \mathrm{~km}$ depth. Christensen (1996) made measurements of shear wave velocities at pressures up to $1 \mathrm{GPa}$ for 678 rock types. Assuming a mean crustal density of $2830 \mathrm{~kg} \mathrm{~m}^{-3}$ (Christensen \& Mooney 1995), the pressure in the lower crust at $25 \mathrm{~km}$ depth is $\sim 700 \mathrm{MPa}$. Christensen (1996) reported shear velocities at $700 \mathrm{MPa}$ of $3.82 \mathrm{~km} \mathrm{~s}^{-1}$ for mafic granulite, $4.03 \mathrm{~km} \mathrm{~s}^{-1}$ for mafic garnet granulite and $3.65 \mathrm{~km} \mathrm{~s}^{-1}$ for felsic granulite. This implies that the high shear velocity zone at $25 \mathrm{~km}$ depth may be composed of mafic granulite. However, associating rock type to seismic velocities is highly non-unique, with temperature being a critical factor. At these pressures, amphibolite is also a plausible fit for these velocities if there was not enough heat to generate granulite. That said, granulite is detected in other high-velocity lower crustal zones and is attributed to magmatic underplating (e.g. Clowes et al. 2002; Kuusisto et al. 2006; Peltonen et al. 2006). If failed rifting and underplating provided enough heat, then according to these laboratory-based results, the best fit for the composition of the NW-trending high shear velocity is mafic granulite. It is also possible that mafic intrusions are the cause of other velocity highs elsewhere in the lower crust (e.g. north of King Island and below Torquay sub-basin), but locally thinned crust could also produce this effect, since shear wave velocities in the mantle lithosphere are much higher in comparison to the crust.

The hypothesis linking mainland Australia and Tasmania via the Selwyn Block is based in part on the NE-trending magnetic lineament that extends from south of King Island up to central Victoria. Fig. 10(c) is a magnetic anomaly map of the region, overlain with the extent of the Selwyn Block at $25 \mathrm{~km}$ depth as proposed by Pilia et al. (2015b) and the outline of the Selwyn block according to Moore et al. (2016), based on surface geology and potential field data. This NW-trending zone includes many small-scale terminations of linear magnetic anomalies (Fig. 10c), within the bounds of the anomalously high velocities $>3.8 \mathrm{~km} \mathrm{~s}^{-1}$ (Fig. 10b). These small discontinuities are likely due to faulting during failed rifting and subsequent basin formation in Bass Strait. Apparent terminations may also be due to overprinting of magnetic anomalies by more recent volcanic material. The most recent and extensive period of volcanism in the Bass Basin occurred in the Oligocene-Miocene, where igneous rocks were extruded and intruded throughout the central and northeastern Bass Basin (Smit 1988; Gunn et al. 1997; Cummings et al. 2004; Blevin et al. 2005). The distinct high magnetic anomaly (pink) in the centre of Bass Strait is an example of a large body of more recent igneous material.

Gravity data for the area are also available (Fig. 10d), but contains less detail than the magnetic data. The dominant gravity anomalies in the image are west and east of Tasmania, corresponding to the present day location of the edge of the continental shelf. The lower crustal high velocity zone and the limits of the Selwyn Block estimated by Pilia et al. (2015b) are overlaid on the map. Gravity anomalies in the centre of Bass Strait appear to have some NW-SE orientation and parts of the high velocity zone (from $145^{\circ}-146.5^{\circ}$ ) correspond closely to the gravity low in the vicinity of the Bass Basin. The Selwyn Block extent, confirmed in the south by our new model, somewhat corresponds to discontinuities in gravity anomalies. In particular, low gravity values in north Tasmania and just offshore, correlate to the location of transition from lower shear velocities in the west to higher velocities in the east, and the edge of the Selwyn Block. 
(a)

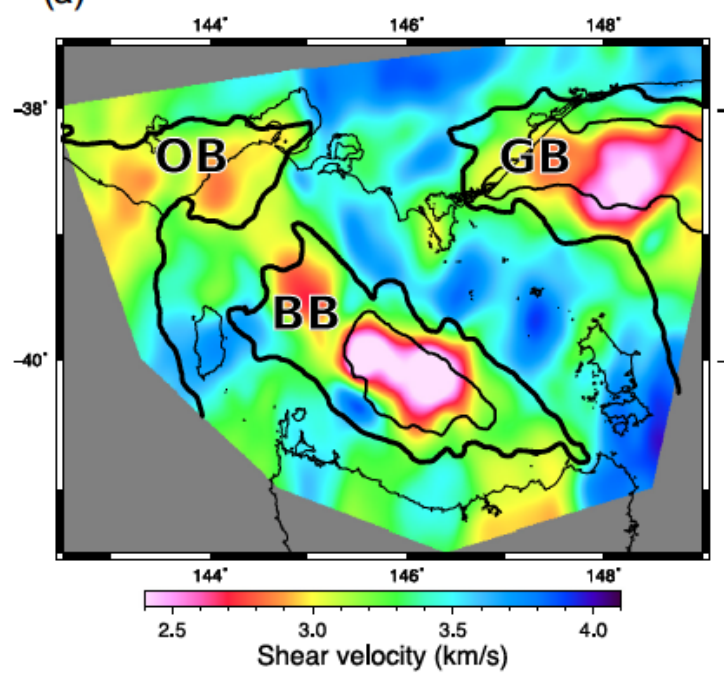

(c)

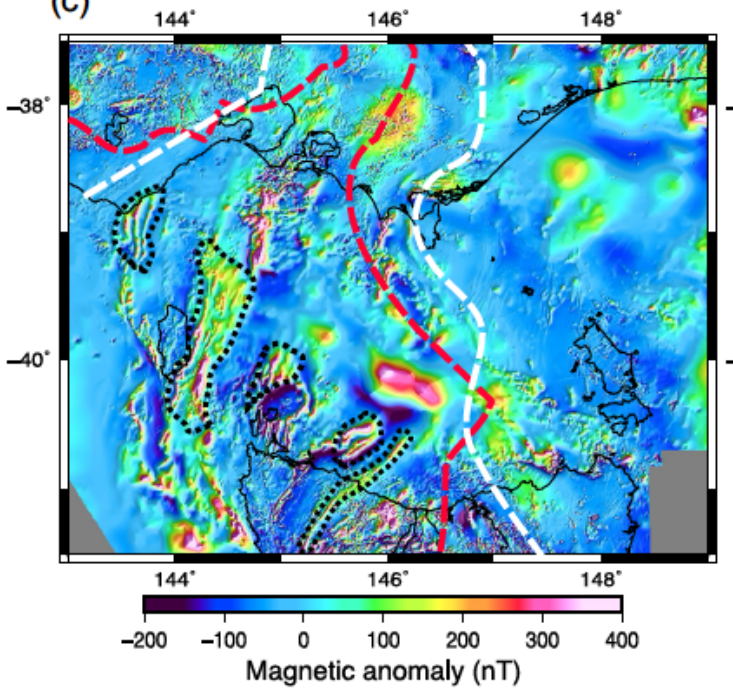

(b)

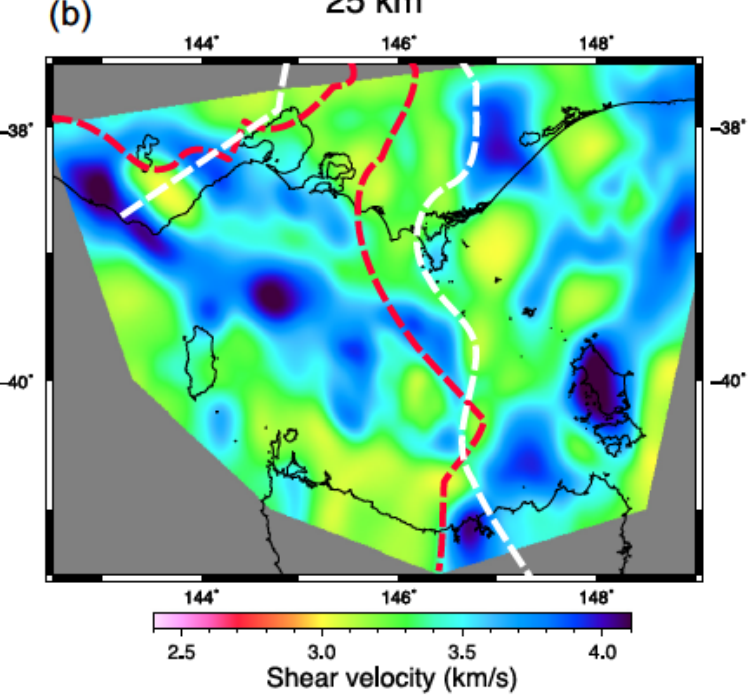

(d)

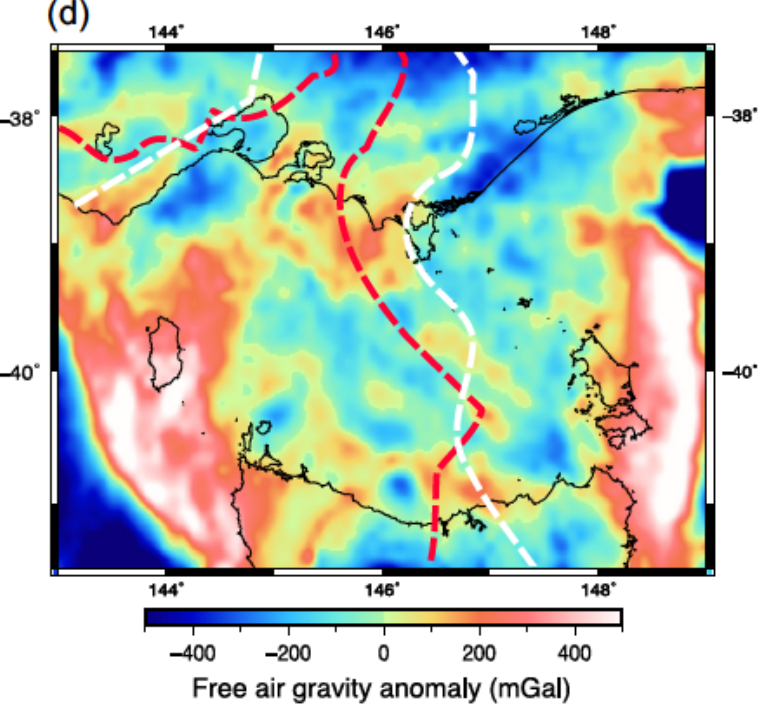

Figure 10. (a) $5 \mathrm{~km}$ depth slice overlaid with traces of basin outlines from SEEBASE ${ }^{\mathrm{TM}}$ (Teasdale et al. 2001), with sediment thickness contours at $\sim 1500 \mathrm{~m}$ (thicker black line) and $\sim 6000 \mathrm{~m}$ (thinner black line) to show main depocentres, (b) $25 \mathrm{~km}$ depth slice overlaid with the extent of Selwyn Block according to Moore et al. (2016; red dashed) and from the shear velocity model of Pilia et al. (2015) at $25 \mathrm{~km}$ depth (white dashed line), (c) magnetic anomaly map with lineation terminations in dashed circles, (d) free air gravity map, both with the same overlays as (b). Gravity and magnetic data downloaded from Geoscience Australia.

There is evidence for widespread igneous activity across all of the failed branches of the southern margin rift system until $5 \mathrm{Ka}$ (e.g. Johnson 1989; Meeuws et al. 2016). The Bass, Otway and Gippsland basins all contain mafic intrusive and extrusive rocks, whose age generally coincides with the failed rifting event and subsequent compressional reactivation of the region (e.g. Lennon et al. 1999; Cummings et al. 2004; Schneider et al. 2004; Holford et al. 2012; Meeuws et al. 2016). Areas with high concentrations of igneous material correspond well to locations of high shear wave velocity in the lower crust in our model. In particular, the NW-SE high-velocity zone stretching from the Otway to the Bass Basin at depths $>15 \mathrm{~km}$ appears to underlie major depocentres and areas of documented igneous intrusions and extrusions (Cummings et al. 2004; Holford et al. 2012). Despite the relatively young age of the igneous activity $(<100 \mathrm{Ma})$, it is likely that the high velocities observed along the failed rift zone today are related. There are many examples of rifts that appear to be underlain by high velocity zones in the lower crust including the Baikal rift (Thybo \& Nielsen 2009), the southern Kenyan Rift (Birt et al. 1997), DonBas rift in Ukraine (Maystrenko et al. 2003) and Oslo Graben rift structure (Stratford \& Thybo 2011). High velocity lower crust in such regions has been interpreted as evidence for substantial magmatic intrusion during rifting to compensate for crustal thinning (Lyngsie et al. 2007). It is possible that the high shear wave velocities observed below the failed rift system of the Otway, Bass and Gippsland basins represent mafic material at the base of the crust. In the case of the Bass Basin, Moore et al. (2016) showed that the presence of mafic material in the underlying crust is consistent with models derived from gravity data. Furthermore, igneous material appears to exploit pre-existing faults in the upper crust according to seismic reflection data across the Bass Strait basins (e.g. Smit 1988; Lennon et al. 1999; Cummings et al. 2004). Mafic material from the mantle exploiting the crustal weakness associated with the Southern Margin failed rift may be the reason for the high shear wave velocity lineament in our model. Movement of mafic material upwards through this weakened crust 
is further supported by the prolific intrusive and extrusive rocks across the sedimentary basins.

\section{CONCLUSIONS}

We present the first 3-D shear wave velocity model of Bass Strait generated from phase velocity measurements of ambient seismic noise. Due to noise sources within Bass Strait, previous studies have found it difficult to extract reliable interstation phase velocity dispersion curves. However, by utilizing time-frequency domain phase-weighted stacking to improve the SNR, we were able to successfully extract phase velocity information. A transdimensional, hierarchical, Bayesian inversion method, which is highly data driven and requires minimal tuning of initial parameters, was then applied to invert for shear wave velocity. This approach accounts for heterogeneous data coverage, produces an ensemble of solution models and can constrain data uncertainty parameters. The velocity structures in our model appear to be consistent with many features at or near the surface. In particular, comparison of basin geometries outlined in the shear velocity model with those published from industry sources shows that they are in good agreement. Along southern Victoria, we find that our model can be related to known terrane boundaries at the surface, which correspond to major crustal divisions of the Delamerian and Lachlan orogens. In particular, we identify an east-dipping zone that is present to the base of the crust, and corresponds approximately to the location and dip of the Moyston Fault Zone. This fault is thought to represent the boundary between the Delamerian Orogen and Lachlan Orogen. Our results also reveal an NW-trending lower crustal high-velocity zone that extends across the Selwyn Block from western Victoria (mainland Australia) possibly as far as NE Tasmania. Extensive igneous rocks intruded into sedimentary basins above this fault zone together with the high velocities in the lower crust suggest that mafic material may have exploited this crustal weakness during failed rifting.

\section{ACKNOWLEDGEMENTS}

\section{Acknowledgements}

The work contained in this paper was conducted during a $\mathrm{PhD}$ study undertaken as part of the Natural Environment Research Council (NERC) Centre for Doctoral Training (CDT) in Oil \& Gas [grant number NEM00578X/1]. This work was performed using the Maxwell High Performance Computing Cluster of the University of Aberdeen IT Service (www.abdn.ac.uk/staffnet/research/hpc.php), provided by Dell Inc. and supported by Alces Software. Data were collected with the support of the Australian Research Council under grant number LP110100256. Plots were generated with Generic Mapping Tools (GMT; Wessel et al. 2013). We thank David Moore and Martin Schimmel for constructive reviews that greatly improved our original submission.

\section{REFER E N CES}

Ardhuin, F., Gualtieri, L. \& Stutzmann, E., 2015. How ocean waves rock the Earth: two mechanisms explain microseisms with periods 3 to $300 \mathrm{~s}$, Geophys. Res. Lett., 42(3), 765-772.

Arroucau, P., Rawlinson, N. \& Sambridge, M., 2010. New insight into Cainozoic sedimentary basins and Palaeozoic suture zones in southeast Australia from ambient noise surface wave tomography, Geophys. Res. Lett., 37(7), doi:10.1029/2009GL041974.
Bensen, G.D., Ritzwoller, M.H. \& Shapiro, N.M., 2008. Broadband ambient noise surface wave tomography across the United States, J. geophys. Res., 113(B5), doi:10.1029/2007JB005248.

Berry, R.F., Holm, O.H. \& Steele, D.A., 2005. Chemical U-Th-Pb monazite dating and the Proterozoic history of King Island, southeast Australia, Aust. J. Earth Sci., 52(3), 461-471.

Birch, G.F., 1987. Igneous Rocks of the Gippsland Basin, Esso Australia Ltd.

Birt, C.S., Maguire, P.K.H., Khan, M.A., Thybo, H., Keller, G.R. \& Patel, J., 1997. The influence of pre-existing structures on the evolution of the southern Kenya Rift valley; evidence from seismic and gravity studies, Tectonophysics, 278, 211-242.

Black, L.P., Calver, C.R., Seymour, D.B. \& Reed, A., 2004. SHRIMP U-Pb detrital zircon ages from Proterozoic and Early Palaeozoic sandstones and their bearing on the early geological evolution of Tasmania, Aust. J. Earth Sci., 51(6), 885-900.

Black, L.P., Everard, J.L., McClenaghan, M.P., Korsch, R.J., Calver, C.R., Fioretti, A.M., Brown, A.V. \& Foudoulis, C., 2010. Controls on DevonianCarboniferous magmatism in Tasmania, based on inherited zircon age patterns, $\mathrm{Sr}, \mathrm{Nd}$ and $\mathrm{Pb}$ isotopes, and major and trace element geochemistry, Australian Journal of Earth Sciences, 57(7), 933-968.

Black, L.P., McClenaghan, M.P., Korsch, R.J., Everard, J.L. \& Foudoulis, C., 2005. Significance of Devonian-Carboniferous igneous activity in Tasmania as derived from U-Pb SHRIMP dating of zircon, Aust. J. Earth Sci., 52(6), 807-829.

Blevin, J.E., 2003. Petroleum Geology of the Bass Basin-interpretation Report: An Output of the Western Tasmanian Regional Minerals Program, Geoscience Australia, Department of Industry, Tourism \& Resources.

Blevin, J.E., Trigg, K.R., Partridge, A.D., Boreham, C.J. \& Lang, S.C., 2005. Tectonostratigraphy and potential source rocks of the Bass Basin, APPEA J., 45(1), 601-622.

Bodin, T., Salmon, M., Kennett, B.L.N. \& Sambridge, M., 2012b. Probabilistic surface reconstruction from multiple data sets: an example for the Australian Moho, J. geophys. Res., 117, B10307, doi:10.1029/2012JB009547.

Bodin, T. \& Sambridge, M., 2009. Seismic tomography with the reversible jump algorithm, Geophys. J. Int., 178(3), 1411-1436.

Bodin, T., Sambridge, M., Rawlinson, N. \& Arroucau, P., 2012a. Transdimensional tomography with unknown data noise, Geophys. J. Int., 189, $1536-1556$

Boger, S.D. \& Miller, J.M., 2004. Terminal suturing of Gondwana and the onset of the Ross-Delamerian Orogeny: the cause and effect of an Early Cambrian reconfiguration of plate motions, Earth planet. Sci. Lett., 219(1-2), 35-48.

Calver, C.R., Crowley, J.L., Wingate, M.T.D., Evans, D.A.D., Raub, T.D. \& Schmitz, M.D., 2013. Globally synchronous Marinoan deglaciation indicated by U-Pb geochronology of the Cottons Breccia, Tasmania, Australia, Geology, 41(10), 1127-1130.

Cawood, P.A., 2005. Terra Australis Orogen: Rodinia breakup and development of the Pacific and Iapetus margins of Gondwana during the Neoproterozoic and Paleozoic, Earth Sci. Rev., 69(3-4), 249-279.

Cayley, R.A., 2011. Exotic crustal block accretion to the eastern Gondwanaland margin in the Late Cambrian-Tasmania, the Selwyn Block, and implications for the Cambrian-Silurian evolution of the Ross, Delamerian, and Lachlan orogens, Gondwana Res., 19(3), 628-649.

Cayley, R.A., Taylor, D.H., VandenBerg, A.H.M. \& Moore, D.H., 2002. Proterozoic-Early Palaeozoic rocks and the Tyennan Orogeny in central Victoria: the Selwyn Block and its tectonic implications, Aust. J. Earth Sci., 49(2), 225-254.

Cayley, R.A. et al., 2011. Crustal architecture of central Victoria: results from the 2006 deep crustal reflection seismic survey, Aust. J. Earth Sci., 58(2), 113-156.

Chmielowski, R.M. \& Berry, R.F., 2012. The Cambrian metamorphic history of Tasmania: the metapelites, Australian Journal of Earth Sciences, 59(7), 1007-1019.

Christensen, N.I., 1996. Poisson's ratio and crustal seismology, J. geophys. Res., 101(B2), 3139-3156. 
Christensen, N.I. \& Mooney, W.D., 1995. Seismic velocity structure and composition of the continental crust: a global view, J. geophys. Res., 100(B6), 9761-9788.

Clemens, J.D., Regmi, K., Nicholls, I.A., Weinberg, R. \& Maas, R., 2016. The Tynong pluton, its mafic synplutonic sheets and igneous microgranular enclaves: the nature of the mantle connection in I-type granitic magmas, Contrib. Mineral. Petrol., 171(4), 35.

Clowes, R.M., Burianyk, M.J., Gorman, A.R. \& Kanasewich, E.R., 2002. Crustal velocity structure from SAREX, the southern Alberta refraction experiment, Can. J. Earth Sci., 39(3), 351-373.

Crawford, A.J., Cameron, W.E. \& Keays, R.R., 1984. The association boninite low-Ti andesite-tholeiite in the Heathcote Greenstone Belt, Victoria; ensimatic setting for the early Lachlan Fold Belt, Aust. J. Earth Sci., 31(2), $161-175$.

Cummings, A.M., Hillis, R.R. \& Tingate, P.R., 2004. New perspectives on the structural evolution of the Bass Basin: implications for petroleum prospectivity, in Eastern Australasian Basins Symposium II, pp. 133-149, eds. Boult, P.J., Johns, D.R. \& Lang, S.C.

Dickinson, J.A., Wallace, M.W., Holdgate, G.R., Daniels, J., Gallagher, S.J. \& Thomas, L., 2001. Neogene tectonics in SE Australia: implications for petroleum systems, APPEA J., 41(1), 37-52.

Drummond, B., Barton, T., Korsch, R., Rawlinson, N., Yeates, A., Collins, C. \& Brown, A., 2000. Evidence for crustal extension and inversion in eastern Tasmania, Australia, during the Neoproterozoic and Early Palaeozoic, Tectonophysics, 329(1-4), 1-21.

Etheridge, M., McQueen, H. \& Lambeck, K., 1991. The role of intraplate stress in Tertiary (and Mesozoic) deformation of the Australian continent and its margins: a key factor in petroleum trap formation, Explor. Geophys., 22(1), 123-128.

Fergusson, C.L., 2003. Ordovician-Silurian accretion tectonics of the Lachlan fold belt, southeastern Australia, Aust. J. Earth Sci., 50(4), 475-490.

Fergusson, C.L. \& Coney, P.J., 1992. Implications of a Bengal Fan-type deposit in the Paleozoic Lachlan fold belt of southeastern Australia, Geology, 20(11), 1047-1049.

Flecha, I., Carbonell, R., Zeyen, H., Martí, D., Palomeras, I., Simancas, F. \& Pérez-Estaún, A., 2006. Imaging granitic plutons along the IBERSEIS profile, Tectonophysics, 420(1-2), 37-47.

Flottmann, T., Gibson, G.M. \& Kleinschmidt, G., 1993. Structural continuity of the Ross and Delamerian orogens of Antarctica and Australia along the margin of the paleo-Pacific, Geology, 21, 319-322.

Galetti, E., Curtis, A., Meles, G.A. \& Baptie, B., 2015. Uncertainty loops in travel-time tomography from nonlinear wave physics, Physical review letters, 114(14), 148501.

Gibson, G.M., Morse, M.P., Ireland, T.R. \& Nayak, G.K., 2011. Arccontinent collision and orogenesis in western Tasmanides: insights from reactivated basement structures and formation of an ocean-continent transform boundary off western Tasmania, Gondwana Res., 19(3), 608627.

Glen, R.A., 2013. Refining accretionary orogen models for the Tasmanides of eastern Australia, Aust. J. Earth Sci., 60(3), 315-370.

Gray, D.R., 1997. Tectonics of the southeastern Australian Lachlan Fold Belt: structural and thermal aspects, Geol. Soc. London Spec. Publ., 121(1), $149-177$.

Gray, D.R. \& Foster, D.A., 1998. Character and kinematics of faults within the turbidite-dominated Lachlan Orogen: implications for tectonic evolution of eastern Australia, J. Struct. Geol., 20(12), 1691-1720.

Green, P.J., 1995. Reversible jump Markov chain Monte Carlo computation and Bayesian model determination, Biometrika, 82(4), 711-732.

Gunn, P., Mitchell, J. \& Meixner, A., 1997. The structure and evolution of the Bass basin as delineated by aeromagnetic data, Explor. Geophys., 28(1/2), 214-219.

Gunn, P.J., Maidment, D. \& Milligan, P.R., 1997a. Interpreting aeromagnetic data in areas of limited outcrop, 17, AGSO Journal of Australian geology and geophysics, p. 175-186.

Gunn, P.J., Minty, B.R.S. \& Milligan, P.R., 1997b. The airborne gamma-ray spectrometric response over arid Australian terranes. In Exploration, Vol. 97, p. 733-740.
Halpin, J.A. et al., 2014. Authigenic monazite and detrital zircon dating from the Proterozoic Rocky Cape Group. Tasmania: Links to the Belt-Purcell Supergroup, 250, North America. Precambrian Research, p. 50-67.

Hastings, W.K., 1970. Monte Carlo sampling methods using Markov chains and their applications, Biometrika, 57(1), 97-109.

Hergt, J.M., Chappell, B.W., McCulloch, M.T., McDougall, I. \& Chivas, A.R., 1989. Geochemical and isotopic constraints on the origin of the Jurassic dolerites of Tasmania, J. Petrol., 30(4), 841-883.

Hill, K.C., Hill, K.A., Cooper, G.T., O'Sullivan, A.J., O'Sullivan, P.B. \& Richardson, M.J., 1995. Inversion around the Bass basin, SE Australia, Geol. Soc. London Spec. Publ., 88(1), 525-547.

Hill, P.J., Moore, A.M.G. \& Exon, N.F., 2001. Sedimentary basins and structural framework of the South Tasman Rise and East Tasman Plateau, in Eastern Australasian Basins Symposium, a Refocused Energy Perspective for the Future, pp. 37-48, eds Hill, K.C. \& Bernecker, T., PESA Special Publication.

Holford, S., Schofield, N., MacDonald, J., Duddy, I. \& Green, P., 2012. Seismic analysis of igneous systems in sedimentary basins and their impacts on hydrocarbon prospectivity: examples from the southern Australian margin, APPEA J., 52(1), 229-252.

Johnson, R.W., Johnson, R.W., Knutson, J. \& Taylor, S.R.eds, 1989. Intraplate Volcanism: In Eastern Australia and New Zealand, Cambridge Univ. Press.

Korsch, R.J., Barton, T.J., Gray, D.R., Owen, A.J. \& Foster, D.A., 2002. Geological interpretation of a deep seismic-reflection transect across the boundary between the Delamerian and Lachlan Orogens, in the vicinity of the Grampians, western Victoria, Aust. J. Earth Sci., 49(6), 1057-1075.

Kuusisto, M., Kukkonen, I.T., Heikkinen, P. \& Pesonen, L.J., 2006. Lithological interpretation of crustal composition in the Fennoscandian Shield with seismic velocity data, Tectonophysics, 420(1-2), 283-299.

Leaman, D., Baillie, P. \& Powell, C.M., 1994. Precambrian Tasmania: a thin-skinned devil, Explor. Geophys., 25(1), 19-23. 72, 78.

Lennon, R.G., Suttill, R.J., Guthrie, D.A. \& Waldron, A.R., 1999. The renewed search for oil and gas in the Bass Basin: results of Yolla-2 and White Ibis-1, APPEA J., 39(1), 248-262.

Levshin, A.L. \& Ritzwoller, M.H., 2001. Automated detection, extraction, and measurement, of regional surface waves, Pure appl. Geophys., 158, $1531-1545$,

Li, Z.X., Baillie, P.W. \& Powell, C.M., 1997. Relationship between northwestern Tasmania and east Gondwanaland in the late Cambrian/early Ordovician: paleomagnetic evidence, Tectonics, 16(1), 161-171.

Longuet-Higgins, M.S., 1950. A theory of the origin of microseisms, Phil. Trans. R. Soc. Lond., A, 243(857), 1-35.

Lyngsie, S.B., Thybo, H. \& Lang, R., 2007. Rifting and lower crustal reflectivity: a case study of the intracratonic Dniepr-Donets rift zone, Ukraine, J. geophys. Res., 112, B12402, doi:10.1029/2006JB004795.

Maystrenko, Y., Stovba, S., Stephenson, R. \& Bayer, U., 2003. Crustal-scale pop-up structure in cratonic lithosphere; DOBRE deep seismic reflection study of the Donbas fold belt, Ukraine, Geology, 31, 733-736.

McClenaghan, M.P., 2006. The geochemistry of tasmanian DevonianCarboniferous granites and implications for the composition of their source rock, Tasmanian Geol. Surv.

McLean, M.A., Morand, V.J. \& Cayley, R.A., 2010. Gravity and magnetic modelling of crustal structure in central Victoria: what lies under the Melbourne Zone?, Aust. J. Earth Sci., 57(2), 153-173.

McPhail, A., 2000. A petrographic and geochemical study of Gippsland Basin volcanics, BSc Honours thesis, University of Adelaide, National Centre for Petroleum Geology and Geophysics.

Meeuws, F.J., Holford, S.P., Foden, J.D. \& Schofield, N., 2016. Distribution, chronology and causes of Cretaceous-Cenozoic magmatism along the magma-poor rifted southern Australian margin: Links between mantle melting and basin formation, Mar. Pet. Geol., 73, 271-298.

Metropolis, N., Rosenbluth, A.W., Rosenbluth, M.N., Teller, A.H. \& Teller, E., 1953. Equation of state calculations by fast computing machines, $J$. Chem. Phys., 21(6), 1087-1092.

Miller, J.M., Phillips, D., Wilson, C.J.L. \& Dugdale, L.J., 2005. Evolution of a reworked orogenic zone: the boundary between the Delamerian and 
Lachlan Fold Belts, southeastern Australia, Aust. J. Earth Sci., 52(6), 921-940.

Moore, D.H., Betts, P.G. \& Hall, M., 2013. Towards understanding the early Gondwanan margin in southeastern Australia, Gondwana Res., 23(4), $1581-1598$.

Moore, D.H., Betts, P.G. \& Hall, M., 2016. Constraining the VanDieland microcontinent at the edge of East Gondwana, Australia, Tectonophysics, 687, 158-179.

Moresi, L., Betts, P.G., Miller, M.S. \& Cayley, R.A., 2014. Dynamics of continental accretion, Nature, 508(7495), 245.

Morse, M., Gibson, G. \& Mitchell, C., 2009. Basement constraints on offshore basin architecture as determined by new aeromagnetic data acquired over Bass Strait and western margin of Tasmania, ASEG Extended Abstracts, 2009(1), 1-9.

Norvick, M.S. \& Smith, M.A., 2001. Mapping the plate tectonic reconstruction of southern and southeastern Australia and implications for petroleum systems, APPEA J., 41(1), 15-35.

O'Halloran, G.J. \& Johnstone, E.M., 2001. Late Cretaceous rift volcanics of the Gippsland Basin, SE Australia-New insights from 3D seismic, in Eastern Australasian Basins Symposium, A Refocussed Energy Perspective for the Future., ,Hill, K.C. \& ,Bernecker, T., PESA, Special Publication, 353-361.

Ogden, T.E., McLean, M.A., Rawling, T.J. \& Cayley, R.A., 2016. Redefined crustal structure of the Buchan Rift, northeast Victoria: evidence from potential field modelling of newly acquired land-based gravity data, Australian Journal of Earth Sciences, 63(5), 551-570.

Orth, K., VandenBerg, A.H.M., Nott, R.J. \& Simons, B.A., 1995. Murrindal 1: 100000 map geological report., Geological Survey of Victoria Report., Vol. 100p. 237.

Peltonen, P., Mänttäri, I., Huhma, H. \& Whitehouse, M.J., 2006. Multistage origin of the lower crust of the Karelian craton from 3.5 to $1.7 \mathrm{Ga}$ based on isotopic ages of kimberlite-derived mafic granulite xenoliths, Precambrian Res., 147(1-2), 107-123.

Pilia, S., Arroucau, P., Rawlinson, N., Reading, A.M. \& Cayley, R.A., 2016. Inherited crustal deformation along the East Gondwana margin revealed by seismic anisotropy tomography, Geophys. Res. Lett., 43(23).

Pilia, S., Rawlinson, N., Cayley, R., Bodin, T., Musgrave, R., Reading, A., Direen, N. \& Young, M., 2015b. Evidence of micro-continent entrainment during crustal accretion, Sci. Rep., 5, 8212

Pilia, S., Rawlinson, N., Direen, N.G., Reading, A.M., Cayley, R., Pryer, L., Arroucau, P. \& Duffett, M., 2015a. Linking mainland Australia and Tasmania using ambient seismic noise tomography: implications for the tectonic evolution of the east Gondwana margin, Gondwana Res., 28(3), $1212-1227$.

Powell, C.M., Baillie, P.W., Conaghan, P.J. \& Turner, N.J., 1993. The midPalaeozoic turbiditic Mathinna Group, northeast Tasmania. Aust. J. Earth Sci., 40(2), 169-196.

Power, M.R., Hill, K.C., Hoffman, N., Bernecker, T. \& Norvick, M., 2001. The structural and tectonic evolution of the Gippsland Basin: results from 2D section balancing and 3D structural modelling, Eastern Australasian Basins Symposium: a refocused energy perspective for the future: Petroleum Exploration Society of Australia, in ,Hill, K.C. \& ,Bernecker, T., 373-384.

Price, R.C., Nicholls, I.A. \& Gray, C.M., 2003. Cainozoic igneous activity: widespread volcanism resulting from mantle instability and rifting, in Geology of Victoria, Vol.23, pp. 361-375, ed. Birch, W.D., GSA Special Publication.

Rawlinson, N. \& Kennett, B.L.N., 2008. Teleseismic tomography of the upper mantle beneath the southern Lachlan Orogen, Australia, Phys. Earth planet. Inter, 167(1-2), 84-97.

Rawlinson, N. \& Kennett, B.L.N., 2008. Teleseismic tomography of the upper mantle beneath the southern Lachlan Orogen, Physics of the Earth and Planetary Interiors, 167(1-2), 84-97.

Rawlinson, N., Reading, A.M. \& Kennett, B.L., 2006. Lithospheric structure of Tasmania from a novel form of teleseismic tomography, J. geophys. Res., 111(B2), doi:1029/2005JB003803.
Rawlinson, N. \& Sambridge, M., 2004a. Wave front evolution in strongly heterogeneous layered media using the fast marching method, Geophys. J. Int., 156(3), 631-647.

Rawlinson, N. \& Sambridge, M., 2004b. Multiple reflection and transmission phases in complex layered media using a multistage fast marching method, Geophysics, 69(5), 1338-1350.

Richards, J.R. \& Singleton, O.P., 1981. Palaeozoic Victoria, Australia: igneous rocks, ages and their interpretation, J. Geol. Soc. Aust., 28(3-4), 395-421.

Rossiter, A.G., 2003. Granitic rocks of the Lachlan Fold Belt in Victoria, ,Birch, W.D., in Geology of Victoria, Vol. 23, GSA Special Publication, pp. 217-237.

Saito, M., 1988. DISPER80: a subroutine package for the calculation of seismic normal mode solutions, in Seismological Algorithms: Computational Methods and Computer Programs, Vol. 59, pp. 293-319, Academic Press.

Saygin, E. \& Kennett, B.L., 2010. Ambient seismic noise tomography of Australian continent, Tectonophysics, 481(1), 116-125.

Saygin, E. \& Kennett, B.L., 2012. Crustal structure of Australia from ambient seismic noise tomography, J. geophys. Res., 117(B1), doi:10.1029/2011JB008403.

Schimmel, M., Stutzmann, E. \& Gallart, J., 2011. Using instantaneous phase coherence for signal extraction from ambient noise data at a local to a global scale, Geophys. J. Int., 184(1), 494-506.

Schneider, C.L., Hill, K.C. \& Hoffman, N., 2004. Compressional growth of the Minerva Anticline, Otway Basin, Southeast Australia - evidence of oblique rifting, APPEA J., 44(1), 463-480.

Sethian, J.A., 1996. A fast marching level set method for monotonically advancing fronts, Proc. Natl. Acad. Sci. USA, 93(4), 1591-1595.

Sethian, J.A. \& Popovici, A.M., 1999. 3-D traveltime computation using the fast marching method, Geophysics, 64(2), 516-523.

Smit, R., 1988. A new tectonic model for the Bass Basin, Explor. Geophys., 19, 163-168.

Sproll, W.P. \& Dietz, R.S., 1969. Morphological continental drift fit of Australia and Antarctica, Nature, 222(5191), 345-348.

Stratford, W. \& Thybo, H., 2011. Crustal structure and composition of the Oslo Graben, Norway, Earth planet. Sci. Lett., 304, 431-442.

Stump, E., White, A.J.R. \& Borg, S.G., 1986. Reconstruction of Australia and Antarctica: evidence from granites and recent mapping, Earth planet. Sci. Lett., 79, 348-360.

Taylor, D. \& Moore, D., 2009. Victoria's Proterozoic basement controls the distribution of its southern margin petroleum basins, APPEA J., 49(2), 581-581.

Teasdale, J., Pryer, L., Etheridge, M., Stuart-Smith, P., Loutit, T., Shi, Z., Vizy, J. \& Henley, P., 2001. Bass Basin SEEBASE Project. SRK Consulting report, 51.

Teasdale, J. et al., 2002. Otway and Sorell Basins SEEBASE Project. SRK Consulting report, 53.

Teasdale, J.P., Pryer, L.L., Stuart-Smith, P.G., Romine, K.K., Etheridge, M.A., Loutit, T.S. \& Kyan, D.M., 2003. Structural framework and basin evolution of Australia's southern margin, APPEA J., 43(1), 13-37.

Thybo, H. \& Nielsen, C.A., 2009. Magma-compensated crustal thinning in continental rift zones, Nature, 457(7231), 873-876.

VandenBerg, A.H.M., 1999. Timing of orogenic events in the Lachlan Orogen, Aust. J. Earth Sci., 46(5), 691-701.

VandenBerg, A.H.M. \& Stewart, I.R., 1992. Ordovician terranes of the southeastern Lachlan Fold Belt: stratigraphy, structure and palaeogeographic reconstruction, Tectonophysics, 214(1-4), 159-176.

VandenBerg, A.H.M. et al., 2000. The Tasman Fold Belt System in Victoria: Geology and Mineralisation of Proterozoic to Carboniferous Rocks, pp. 462, Geological Survey of Victoria.

Voronoï, G., 1908. Nouvelles applications des paramètres continus à la théorie des formes quadratiques. Deuxième mémoire. Recherches sur les parallélloèdres primitifs, J. Reine Angew. Math., 134, 198-287.

Wessel, P., Smith, W.H.F., Scharroo, R., Luis, J.F. \& Wobbe, F., 2013. Generic mapping tools: improved version released, EOS, Trans. Am. geophys. Un., 94, 409-410. 
White, L.T., Gibson, G.M. \& Lister, G.S., 2013. A reassessment of paleogeographic reconstructions of eastern Gondwana: Bringing geology back into the equation, Gondwana Res., 24(3-4), 984-998.

Williams, E., 1978. Tasman fold belt system in tasmania, Tectonophysics, 48(3-4), 159-205.

Wingate, M.T.D., Campbell, I.H., Compston, W. \& Gibson, G.M., 1998. Ion microprobe $\mathrm{U}-\mathrm{Pb}$ ages for Neoproterozoic-basaltic magmatism in south-central Australia and implications for the breakup of Rodinia, Precambrian Res., 87, 135-159.

Yao, H., van der Hilst, R.D. \& de Hoop, M.V., 2006. Surface-wave array tomography in SE Tibet from ambient seismic noise and two-station analysis-I. Phase velocity maps, Geophys. J. Int., 166, 732-744.

Young, M.K., Cayley, R.A., McLean, M.A., Rawlinson, N., Arroucau, P. \& Salmon, M., 2013b. Crustal structure of the east Gondwana margin in southeast Australia revealed by transdimensional ambient seismic noise tomography, Geophys. Res. Lett., 40(16), 4266-4271.

Young, M.K., Rawlinson, N., Arroucau, P., Reading, A.M. \& Tkalčić, H., 2011. High-frequency ambient noise tomography of southeast Australia: New constraints on Tasmania's tectonic past, Geophys. Res. Lett., 38(13), doi:10.1029/2011GL047971.

Young, M.K., Rawlinson, N. \& Bodin, T., 2013a. Transdimensional inversion of ambient seismic noise for 3D shear velocity structure of the Tasmanian crust, Geophysics, 78(3), WB49-WB62.

Zhao, J.X., McCulloch, M.T. \& Korsch, R.J., 1994. Characterisation of a plume-related $\sim 800$ Ma magmatic event and its implications for basin formation in central-southern Australia, Earth planet. Sci. Lett., 121(3-4), 349-367. 